\title{
Novel design and controls for focused DNA microarrays: applications in quality assurance/control and normalization for the Health Canada ToxArray ${ }^{\mathrm{TM}}$
}

\author{
Carole L Yauk ${ }^{* 1}$, Andrew Williams ${ }^{2}$, Sherri Boucher ${ }^{1}$, Lynn M Berndt ${ }^{1}$, \\ Gu Zhou ${ }^{1}$, Jenny L Zheng ${ }^{1}$, Andrea Rowan-Carroll ${ }^{1}$, Hongyan Dong ${ }^{1}$, \\ Iain B Lambert ${ }^{3}$, George R Douglas ${ }^{1}$ and Craig L Parfett ${ }^{1}$
}

\begin{abstract}
Address: ${ }^{1}$ Mutagenesis Section, Environmental and Occupational Toxicology Division, Safe Environments Program, Health Canada, Ottawa Ontario, K1A 0L2, Canada, ${ }^{2 B i o s t a t i s t i c s ~ a n d ~ E p i d e m i o l o g y ~ D i v i s i o n, ~ S a f e ~ E n v i r o n m e n t s ~ P r o g r a m, ~ H e a l t h ~ C a n a d a, ~ O t t a w a, ~ O N, ~ K 1 A ~ 0 K 9, ~ C a n a d a ~}$ and ${ }^{3}$ Department of Biology, Carleton University, 1125 Colonel By Drive, Ottawa, ON, K1S 5B6, Canada.

Email: Carole L Yauk* - carole_yauk@hc-sc.gc.ca; Andrew Williams - Andrew_Williams@hc-sc.gc.ca; Sherri Boucher - sherri_boucher@hcsc.gc.ca; Lynn M Berndt - Lynn_berndt@ @hc-sc.gc.ca; Gu Zhou - Gu_Zhou@hc-sc.gc.ca; Jenny L Zheng - Jenny_zheng@hc-sc.gc.ca; Andrea Rowan-Carroll - Andrea_Rowan-Carroll@hc-sc.gc.ca; Hongyan Dong - Hongyan_Dong@hc-sc.gc.ca; Iain B Lambert - Iain_lambert@carleton.ca; George R Douglas - George_Douglas@hc-sc.gc.ca; Craig L Parfett - Craig_Parfett@hc-sc.gc.ca

* Corresponding author
\end{abstract}

Published: 19 October 2006

BMC Genomics 2006, 7:266 doi:10.1 |86/|47|-2/64-7-266
Received: 12 December 2005

Accepted: 19 October 2006

This article is available from: http://www.biomedcentral.com//47/-2164/7/266

(C) 2006 Yauk et al; licensee BioMed Central Ltd.

This is an Open Access article distributed under the terms of the Creative Commons Attribution License (http://creativecommons.org/licenses/by/2.0), which permits unrestricted use, distribution, and reproduction in any medium, provided the original work is properly cited.

\begin{abstract}
Background: Microarray normalizations typically apply methods that assume absence of global transcript shifts, or absence of changes in internal control features such as housekeeping genes. These normalization approaches are not appropriate for focused arrays with small sets of genes where a large portion may be expected to change. Furthermore, many microarrays lack control features that can be used for quality assurance (QA). Here, we describe a novel external control series integrated with a design feature that addresses the above issues.

Results: An EC dilution series that involves spike-in of a single concentration of the $A$. thaliana chlorophyll synthase gene to hybridize against spotted dilutions $(0.000015$ to $100 \mu \mathrm{M})$ of a single complimentary oligonucleotide representing the gene was developed. The EC series is printed in duplicate within each subgrid of the microarray and covers the full range of signal intensities from background to saturation. The design and placement of the series allows for QA examination of frequently encountered problems in hybridization (e.g., uneven hybridizations) and printing (e.g., cross-spot contamination). Additionally, we demonstrate that the series can be integrated with a LOWESS normalization to improve the detection of differential gene expression (improved sensitivity and predictivity) over LOWESS normalization on its own.

Conclusion: The quality of microarray experiments and the normalization methods used affect the ability to measure accurate changes in gene expression. Novel methods are required for normalization of small focused microarrays, and for incorporating measures of performance and quality. We demonstrate that dilution of oligonucleotides on the microarray itself provides an innovative approach allowing the full dynamic range of the scanner to be covered with a single gene spike-in. The dilution series can be used in a composite normalization to improve detection of differential gene expression and to provide quality control measures.
\end{abstract}




\section{Background}

High-density genomic tools, such as DNA microarrays, provide an important opportunity to study the global response of genomes to particular stressors or conditions. Unfortunately, commercially-available DNA microarrays exhibit several disadvantages when applied to toxicological investigations. For example, in toxicology, the lack of representation of toxicologically-relevant genes on commercial microarrays is an important problem. Statistical issues arising from existing commercial array designs present additional limitations for toxicogenomics experiments. On high-density commercial arrays, the thousands of genes that are not involved in toxic response pathways may remain relatively stable across exposures, thereby weakening the statistical power necessary to identify responsive elements of the genome [1]. Conversely, focused arrays that contain a limited number of features associated with particular biochemical pathways often lack technical and biological control features, such as gene replicates, quality assurance controls and/or normalization features, that are required for experiments in which a large proportion of genes may exhibit differential expression. A final impediment of commercial arrays in applications such as toxicogenomics is their high cost, which hinders the ability to conduct experiments with sufficient numbers of biological samples/replicates. As a result, the use of custom-made focused microarrays has become a popular alternative, allowing the study of genes relevant to a specific hypothesis.

To address the limitations of commercial arrays in toxicogenomics investigations, we have developed a custom mouse oligonucleotide microarray, the HC ToxArray ${ }^{\mathrm{TM}}$, which, by virtue of including genes that respond to a variety of chemical and physical stressors, is more relevant for toxicological studies. Furthermore, we have incorporated an extensive series of controls useful for both quality control and normalization of small focused arrays. Typical microarray analyses rely on normalization methods that assume absence of global transcript shifts, or that use internal control features such as housekeeping genes (e.g., [2]). These normalization approaches are not appropriate for focused arrays with small sets of genes [3,4]. Global unbalanced changes are expected due to small array size and gene selection based on pathways predicted to be involved in a particular response. Furthermore, chemical exposures or other parameters (e.g., phase of growth, developmental stage, tissue, disease, etc.) may affect the stability of housekeeping gene expression $[5,6]$. Therefore, innovative normalization methods are required for these focused arrays (e.g.,)[4,7-9]). The issue of performance measures and quality control standards must be addressed if microarrays are to be applied as tools in regulatory toxicology and risk assessment.
In this study, we describe novel array design features that address the above issues. Specially positioned internal and external control (EC) series on ToxArray ${ }^{\mathrm{TM}}$ were developed and characterized in order to eliminate the effects of these biological variables as well as reduce additional technical sources of variability, including uneven hybridization artifacts, minimal spot replication and print tip carryover. Sensitivity of the array spots to low-abundance RNA species was also estimated. Validation of the EC series for normalization and comparison with another common normalization strategy was achieved by determining the gene expression profile in mouse liver samples following treatment with the hepatotoxin phenobarbital.

\section{Results \\ Description and positioning of control spots}

We developed an external control (EC) dilution series using the Arabidopsis thaliana chlorophyll synthase gene that involves spike-in of a single concentration of the chlorophyll synthase cRNA to hybridize against spotted dilutions $(0.000015$ to $100 \mu \mathrm{M})$ of a single oligonucleotide representing the gene within each sub-grid of the ToxArray $^{\mathrm{TM}}$ (Figure 1 and 2; see Methods). Spots of the EC dilutions series were printed in duplicate and in some cases in triplicate. Random dilutions from the series were printed in an evenly spaced pattern within each subgrid, among the oligonucleotide spots representing mouse genes. Several negative control spots, including a random 70 mer pool and randomized hexamers, were included to assess non-specific hybridization. A specific pattern of buffer spots was positioned to allow calculation of crossspot carryover during printing.

\section{Evaluation of background, cross-hybridization, signal intensity range and concentration dependence for ToxArray $^{\mathrm{TM}}$ external control features}

A BLASTN search of the 70 base oligonucleotide sequence across GENBANK, EMBL, PDB and DDBJ sequence repositories showed significant homologies only with Arabidopsis thaliana, Oryza sativa and Zea mays DNA and RNA sequences. As expected, hybridization of Universal Mouse Reference RNA (Stratagene) or B6C3F1 liver RNA did not result in detectable signal from any of the EC probe dilutions (data not shown). The spotted A. thaliana EC dilution series was designed to cover the full range of signal intensities obtained with murine-specific oligonucleotides on the ToxArray ${ }^{\mathrm{TM}}$, from background levels to saturation (Figure 3,4$)$. Standard deviation of the $\log _{2}(\mathrm{Cy} 5 /$ Cy3) intensity ratios across the range of EC spike-in self vs. self hybridization results obtained in the presence of murine cRNA (Figure 4, black circles) was approximately $0.4\left(\log _{2}\right)$, prior to normalization. In comparison to the EC spike-in result, a much larger variance was observed in the $\log _{2}(\mathrm{Cy} 5 / \mathrm{Cy} 3)$ intensity ratios typical of a B6C3F1 liver sample vs. Stratagene Universal Reference RNA 


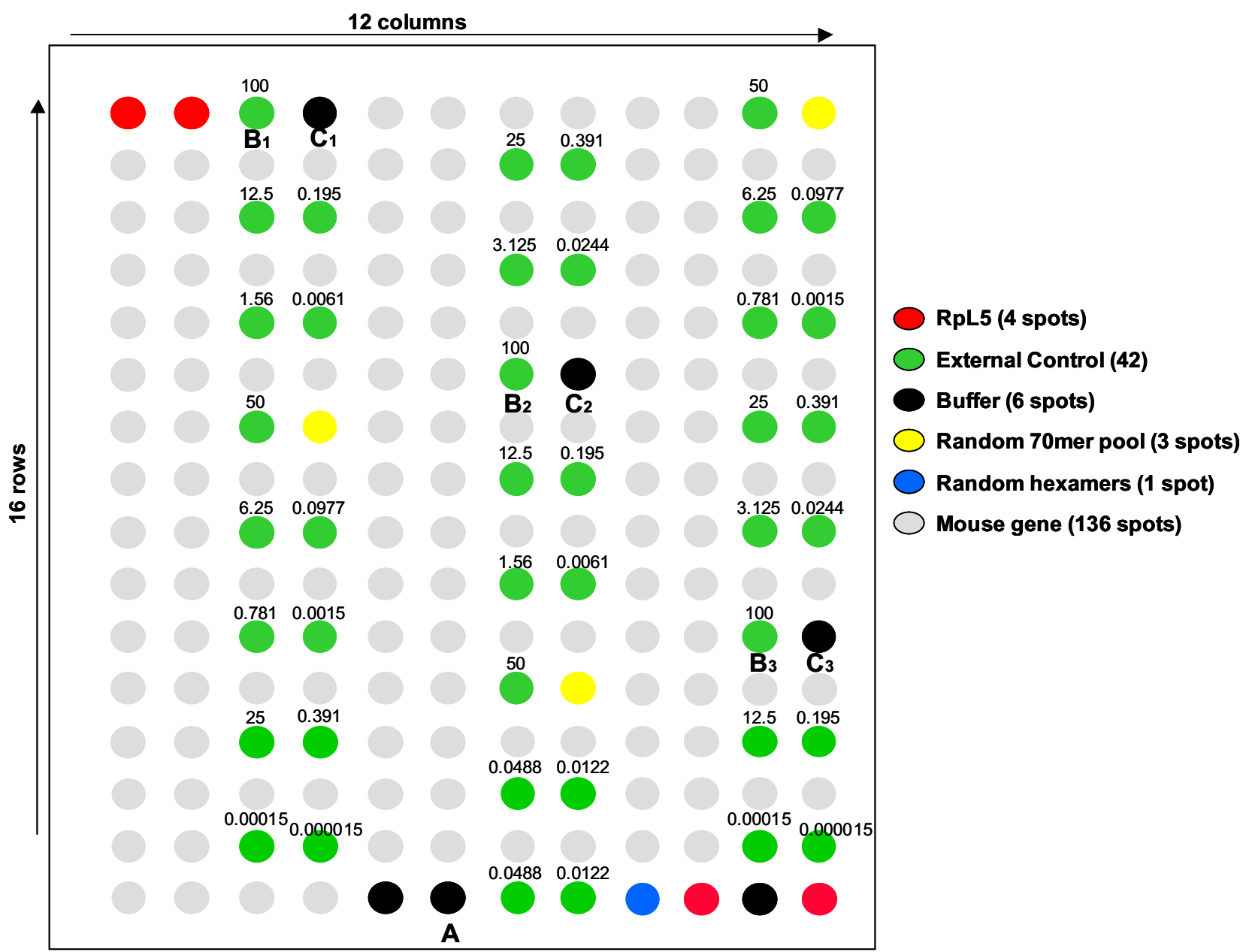

Figure I

Schematic of the design of one sub-grid of the ToxArray ${ }^{\mathrm{TM}}$. Each sub-grid is printed in quadruplicate by one pin. Printing proceeds left-to-right across rows and top row to bottom row. Spot A (bottom row) represents a buffer-only negative control that is printed immediately following another buffer-only spot. $B_{1}$ through $B_{3}$ spots are $100 \mu M A$. thaliana spots which reach saturation. Spots $C_{1}$ through $C_{3}$ are buffer-only spots that are printed immediately following $B$ spots. The average signals from these spots were used to calculate the amount of cross-spot contamination (relative to Spot $A$ ) using the formula: $[(\overline{\mathrm{C}}-\mathrm{A}) /(\overline{\mathrm{B}}-\mathrm{A})] \times 100$

hybridization result (Figure 4 , green circles). The large variation in intensity ratios in the murine cRNA hybridizations were expected to occur due to widely varying abundances of specific mRNAs within these two very different murine RNA sources [10].

A reciprocal dilution experiment was performed to determine the extent to which on-slide concentrations of an oligonucleotide were mimics of the effects of variable con- centrations of the solution-phase cRNA partner in bimolecular hybridization reactions and therefore suitable for normalizing experimental variations in cRNA hybridization. Results from the on-slide dilution series were compared to results from a reciprocal dilution series of the spike-in reference cRNA made in solution. Hybridization of the spotted dilution series with mouse RNA containing a single spike-in concentration of the external reference RNA produced identical profiles of signal intensities com- 


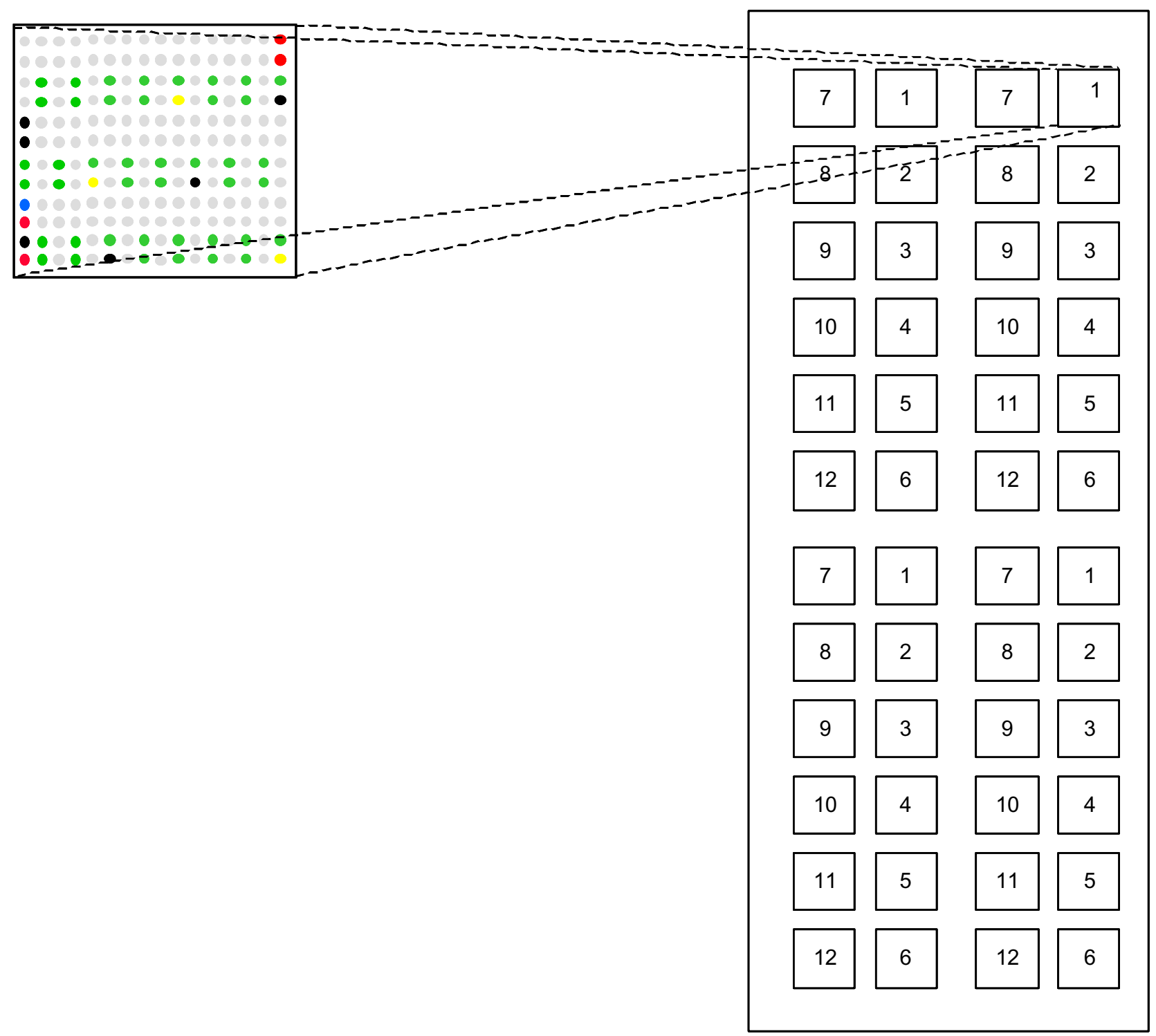

Figure 2

Schematic of the design of one sub-grid and its relative position on a slide of the ToxArray ${ }^{\mathrm{TM}}$. Each sub-grid is printed in quadruplicate by one pin. For example, all of the spots in sub grids numbered I are printed by the same pin.

pared to the signals obtained from multiple slides hybridized with serial spike-in dilutions of the external reference RNA (Figure 5).

\section{Estimation of sensitivity of ToxArray ${ }^{\mathrm{TM}}$ to low-abundance mRNA species}

The fractional sensitivity of the ToxArray ${ }^{\mathrm{TM}}$ oligonucleotide spots was estimated from hybridizations of the serial dilutions of A. thaliana cRNA into a constant amount of cRNA
$(25 \mu \mathrm{g})$ made from the murine polyA+ mRNA, as shown in Figure 5. The smallest fraction tested, 0.0000005 (ng A. thaliana cRNA/ng mouse cRNA), gave significantly greater signal intensity than background from buffer-only spots located on the same slide (Figure 6). This level of sensitivity was greater than that necessary to detect one polyA+ mRNA molecule per cell based upon estimates of approximately 300,000 mRNAs per cell [11]. 


\section{Cy 5 channel}

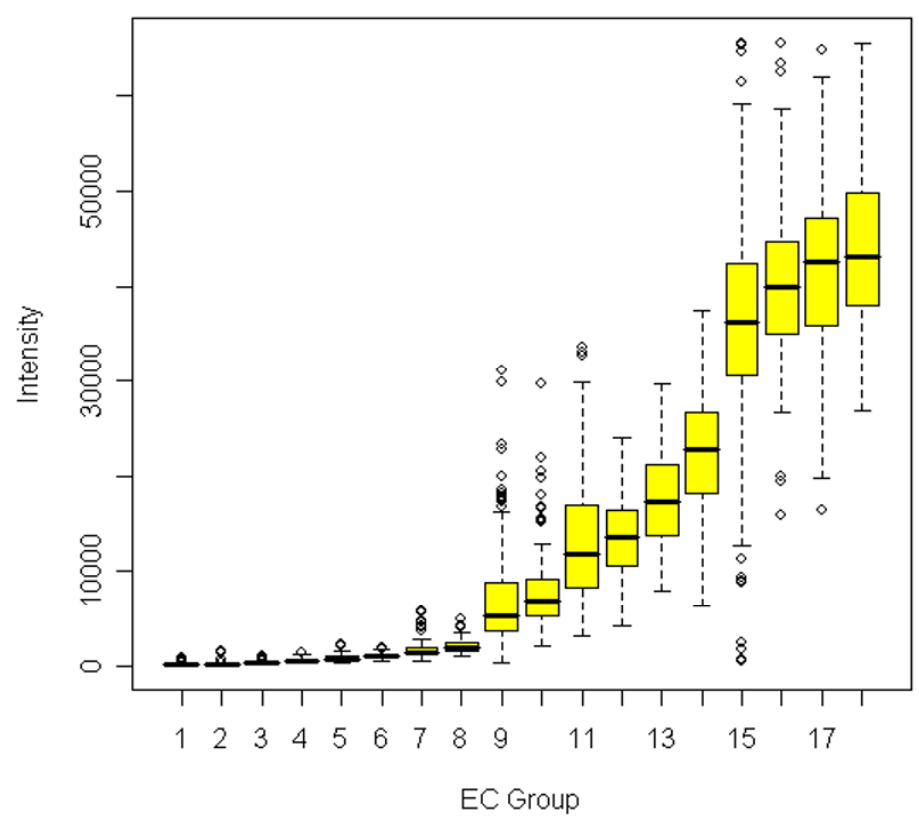

Cy 3 channel

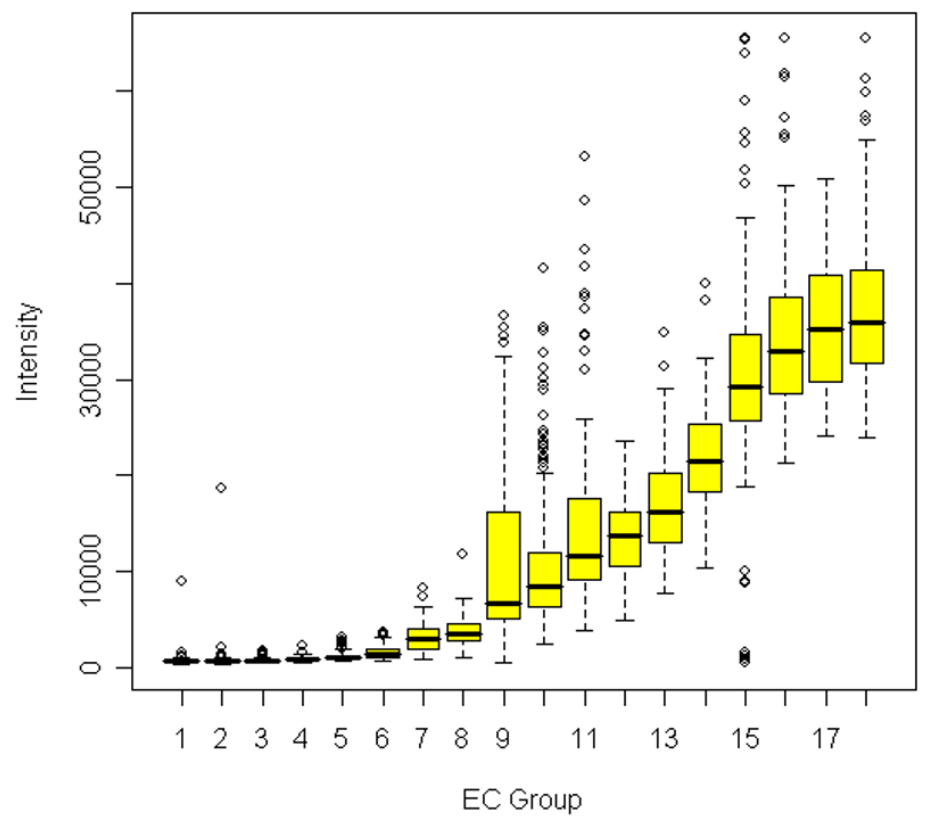

Figure 3

A box plot of signal intensities for each dilution of the Arabidopsis thaliana chlorophyll synthase oligonucleotide target on the ToxArray ${ }^{\mathrm{TM}}$ is plotted for a typical single hybridization containing experiment and reference samples, each with $\mathrm{EC}$ spike-in. Values are raw signal intensities from all spots of each dilution, across all 48 sub-grids. Signal at the greatest dilutions reaches background levels (same intensities as negative controls) and saturation occurs on some spots at the $100 \mu \mathrm{M}$ dilution. 


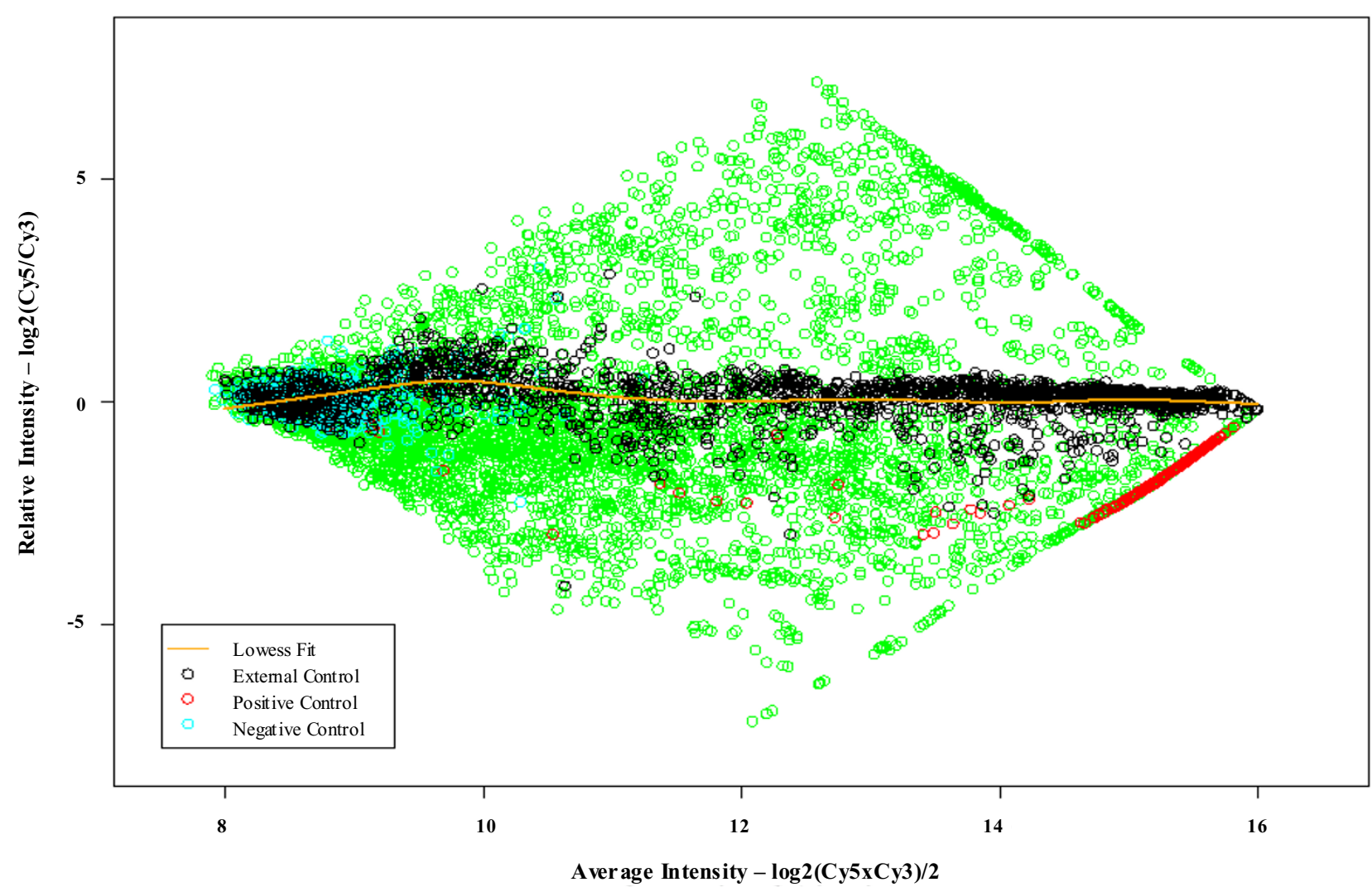

Figure 4

MA plot (log-ratio of the expression intensities versus the mean log-expression of the intensities) for a typical ToxArray ${ }^{\mathrm{TM}}$ hybridization containing a mouse liver experimental RNA sample (Cy5-labeled) and Stratagene Universal Reference RNA (Cy3labeled), each with A. thaliana spike-in control RNA added prior to labelling. The green circles indicate the mouse genes and red circles are the Rpl5 gene which reached scanner saturation in the Cy3 channel at many spots. The EC series covers the full range of signal intensities with no signal gaps. The LOWESS fit shown is through the external controls only, with a span of 0.3 .

\section{Detection of positional artifacts using the EC series}

Because each individual on-slide dilution is printed two to three times within each sub-grid, the design allows for a simple evaluation of differential hybridization (grid to grid) on every array. For example, in initial experiments we detected differential hybridization from right to left and top to bottom of our early slides (Figure 7) that was related to the location on the slide relative to the port of injection of hybridization solution on the automated hybridization station. To some extent, the median of the four widely spaced replicate subgrids would normalize less severe systematic end-to-end and side-to-side variations in hybridization intensity that might be produced by automated hybridization station solution injection, since increased hybridization in one area would tend to be compensated by decreased hybridization in another. In the RNA profiling experiment reported in this work, hybridization results with similar defects were excluded, in favor of patterns with less overall difference in intensities across the slide (Figure 8).

\section{Assessments of negative control spots and print-tip carryover}

All three types of negative controls (buffer-only, random 70 mer oligonucleotide pools and random hexamers) showed similar signal intensities within sub-grids indicating: 1) low background signal from the slide substrate and printing process, and 2) that the presence of non-specific oligonucleotides within a spot did not create hybridization artifacts (data not shown). The amount of print-tip carry-over of oligonucleotides from spot-to-spot during the printing-process was determined by considering the signal of buffer spots that were printed prior to (Spot A in Figure 1) and immediately following the saturated signal (Spot $\mathrm{C}_{1}$ through $\mathrm{C}_{3}$ in Figure 1) associated with the 100 $\mu \mathrm{M}$ A. thaliana oligonucleotide (Spot B in Figure 1). Percent cross-spot contamination was calculated by subtract- 


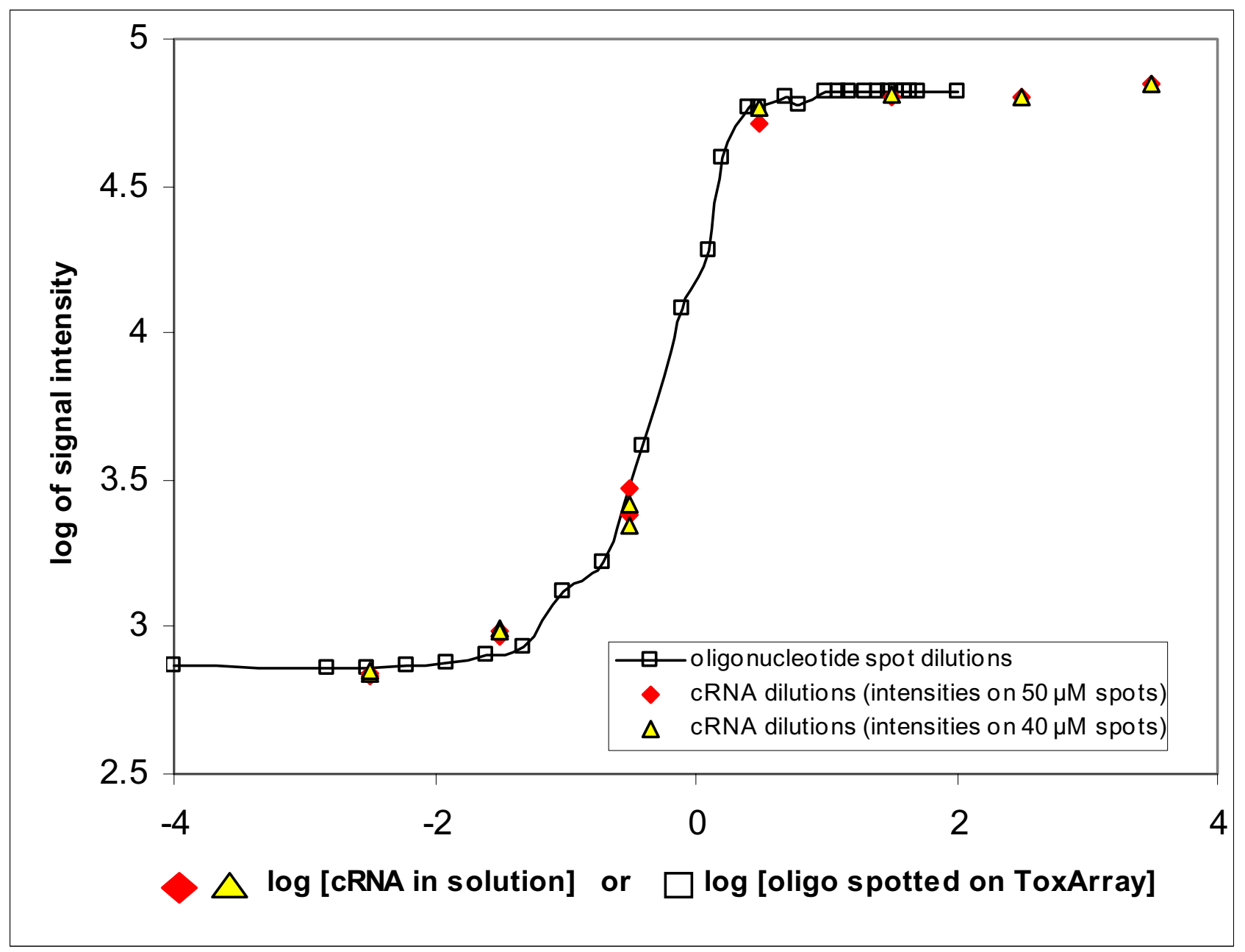

\section{Figure 5}

Comparison of effects of dilution of $A$. thaliana spike-in reference RNA in solution (target) and dilution of on-chip, spotted reference oligonucleotide (probe) in mouse cRNA hybridization reactions. Background-subtracted signal intensities are plotted against relative solution CRNA or attached oligonucleotide spot concentrations. Several murine genes with a range of expression levels were employed for slide-to-slide normalization of the spike-in RNA dilution series hybridization results.

ing the signal of the buffer-only spot (Spot A) from the mean of spots printed immediately following a saturated signal (Spots $\mathrm{C}_{1}$ though $\mathrm{C}_{3}$ ), divided by the mean signal intensity of the saturated spot (Spots $B_{1}$ though $B_{3}$ ) minus the buffer-only background (Spot A) (i.e., [C-A]/[B-A] × 100, from Figure 1; grids are printed left to right). A plot showing a chip with a high proportion of cross-spot contamination for several print groups (groups 1, 2, 7 and 8) is shown in Figure 9. Using this measure, the average cross-spot contamination in the separately printed arrays of the PB RNA profiling experiment was $0.60 \%( \pm 0.02$ standard error) and $0.67 \%$ ( \pm 0.02 standard error) for Cy5 and $\mathrm{Cy} 3$ respectively.
Two additional estimations of carryover artifact amount and frequency could be made from other spot juxtapositions existing within each subgrid. In the first case, three $50 \mu \mathrm{M}$ spots were printed prior to three random-70 mer oligonucleotide pool spots. This situation was directly comparable to most of the oligonucleotides representing murine genes, in that carryover from the first spot would be deposited into the following $40 \mu \mathrm{M}$ spot, rather than buffer. Among arrays employed in the PB experiment described below, we found that the frequency of pins displaying carryover from $50 \mu \mathrm{M}$ EC spots into the 70 mer pool spots was less (by 2 to 3 -fold on a per-pin basis) than the estimate from the $100 \mu \mathrm{M}$ spot analysis. By design, both $100 \mu \mathrm{M}$ spots and the $50 \mu \mathrm{M}$ EC spots gave hybridization signals that were near to, or fully saturated, thus 


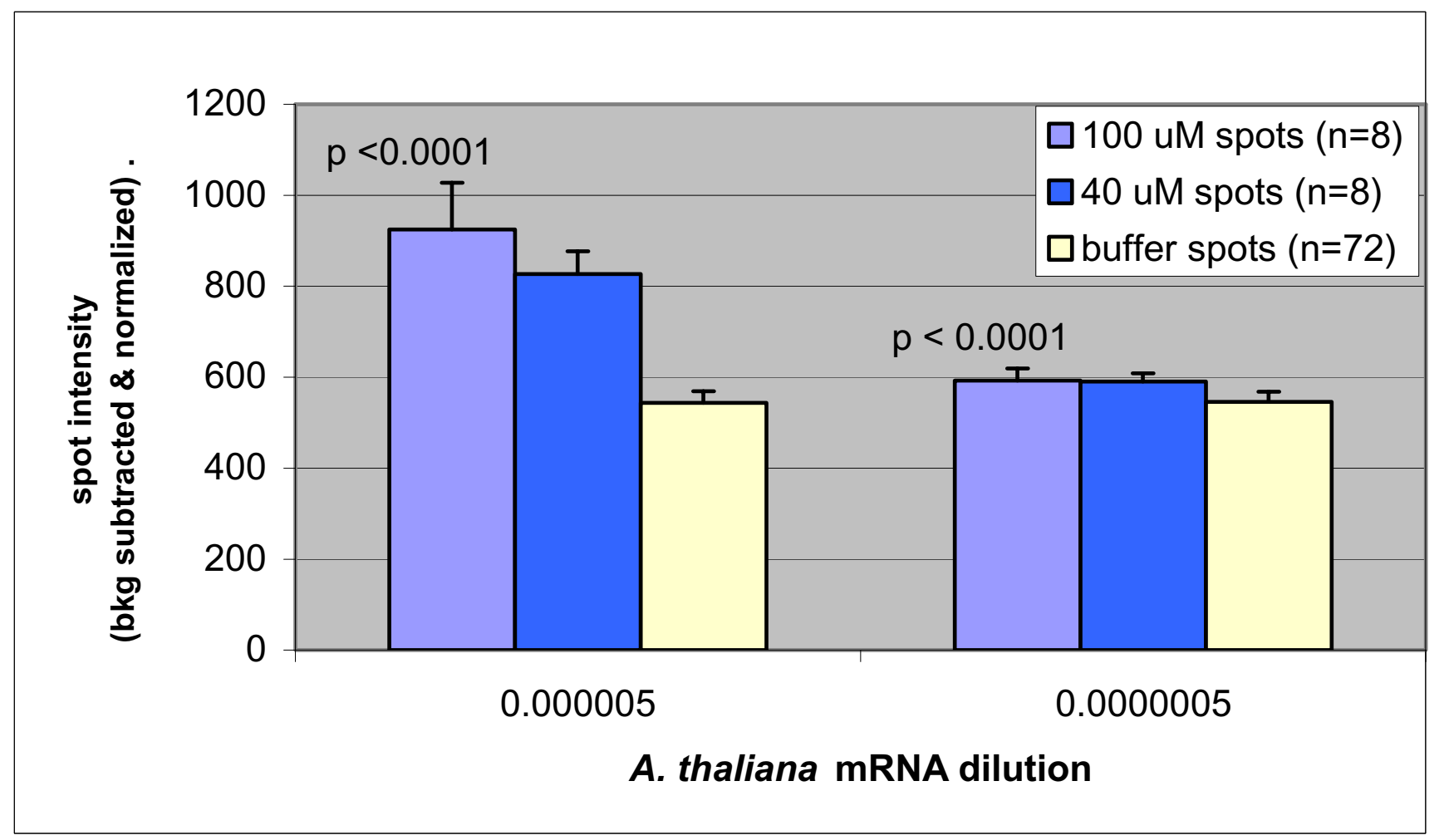

Figure 6

Low abundance sensitivity of the ToxArray ${ }^{\text {TM }}$ at the two lowest fractions of $A$. thaliana cRNA in $25 \mu g$ of murine cRNA (from dilution data shown in figure 4, above) ( $P$ values from t-tests of normalized intensities of $A$. thaliana oligonucleotide and buffer spots). Array-to-array intensities of $40 \mu \mathrm{M}$ A. thaliana spots were normalized to averaged signal from 72 buffer spots, 72 randomized 70 mers, 8 random hexamer spots $(40 \mu \mathrm{M})$ and eight $40 \mu \mathrm{M}$ spots of each of three murine genes with raw intensities near that of $40 \mu \mathrm{M}$. thaliana spots distributed on each array.

providing optimal levels of signal to determine carryover. There was also a single RpL5 spot printed ahead of a buffer spot in each grid. RpL 5 usually also had very high signal levels that approached or reached signal saturation in most hybridizations, allowing another independent estimation of carryover. Only a single pin displayed carryover in the PB experiment. When measured with the 100 and $50 \mu \mathrm{M}$ EC spots and RpL5 spot described above, that pin produced 2/3,2/3,0/1 individual spots with significant carryover (greater than $0.5 \%$ of signal), respectively.

\section{Comparison of Two Normalization Procedures for Detection of Differential Gene Expression using ToxArray $^{\mathrm{TM}}$ and RT-PCR Validation of Presumptive Differential Gene Expression}

Male B6C3F1 mice were given oral doses of 100, 10, 1 and $0.1 \mathrm{mg} / \mathrm{kg} \mathrm{PB}$ or solvent control. Cy-labeled liver cRNA was hybridized against mouse reference cRNA (Stratagene), and MAANOVA was used to examine whether the ToxArray $^{\mathrm{TM}}$ could detect both expected and novel differential expression resulting from PB exposure. The first analysis employed a composite LOWESS normalization of microarray intensity values. This approach calculated a LOWESS normalization of the median values of all data in each print-tip group in addition to a LOWESS normalization of the chip EC titration series. A normalization constant that combined these two into an intensitydependent, weighted average was used [8]. We found a total of 35 genes that were differentially expressed ( $\mathrm{p}<$ 0.05 using the James-Stein Shrinkage F-Test [12] adjusted for the False Discovery Rate (FDR); Table 1) with respect to the overall treatment effect. These p-values obtained from the Fs-Statistic were estimated using 1000 permutations with residual shuffling. Pairwise comparisons showed that 16 of these genes expressed differential abundances of RNA at the highest dose of PB $(100 \mathrm{mg} / \mathrm{kg})$, while 4 were found to be differential at the $10 \mathrm{mg} / \mathrm{ml}$ dose. No genes were identified as differentially expressed in pairwise comparisons at the $1 \mathrm{mg} / \mathrm{kg}$ dose, nor at the lowest dose $(0.1 \mathrm{mg} / \mathrm{kg}$, not shown).

The 16 genes with significant pairwise comparisons after EC normalization were analysed for possible print-tip carryover artifacts, since in the array batch used in the exper- 
(i)

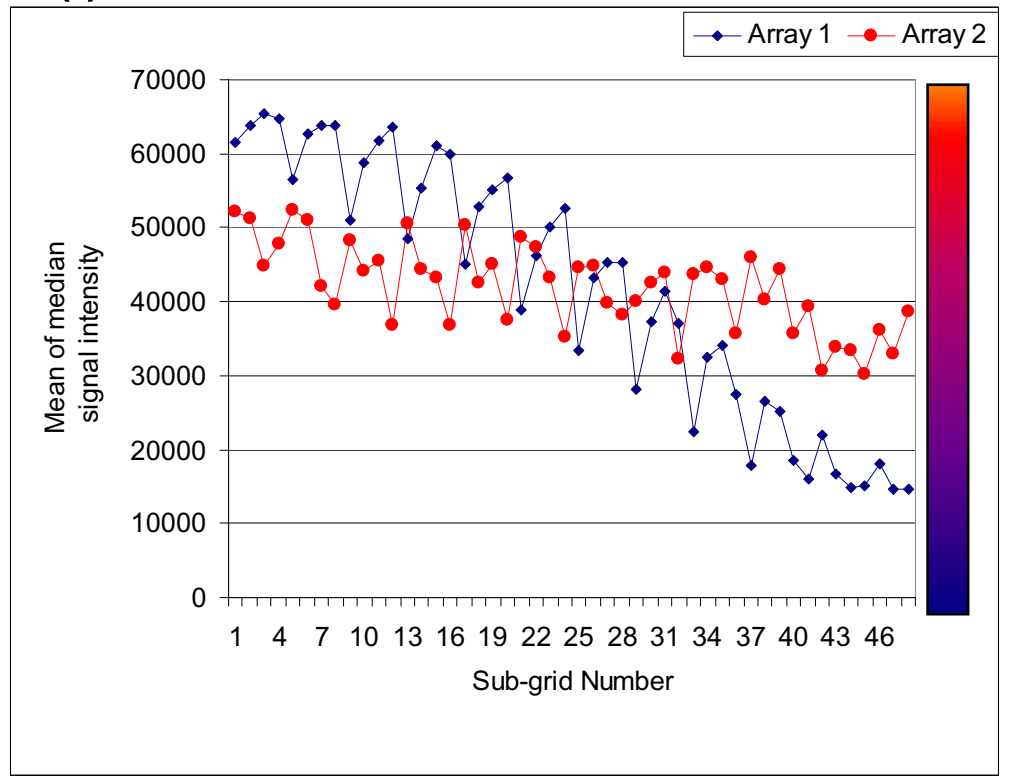

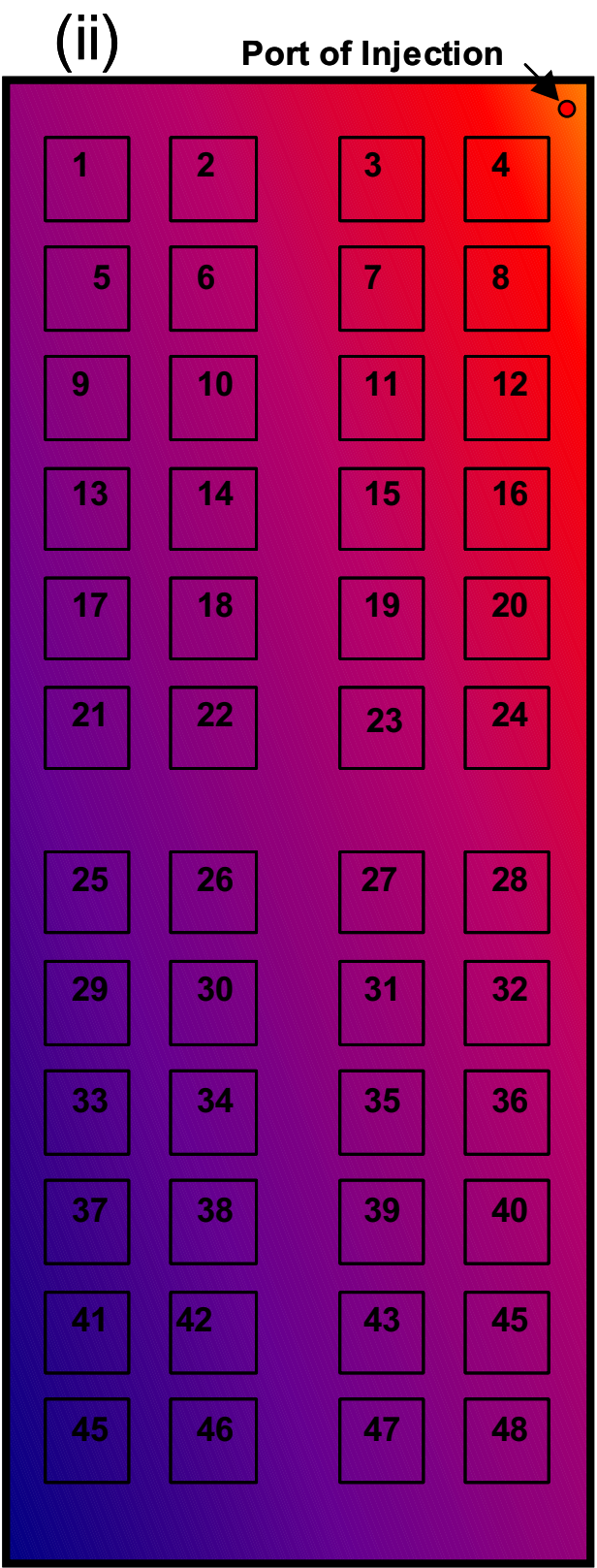

\section{Figure 7}

Detection of uneven hybridization using the EC series. An example of the use of external controls for detection of differential hybridization related to the location on the slide relative to the port of injection of hybridization solution on the automated station. (i) The signal intensity of the $100 \mu \mathrm{M}$ external control is plotted as a function of sub-grid number. Sub-grids are ordered in metacolumns of 4 . The higher the sub-grid number, the closer the sub-grid is to the bottom of the slide. Two arrays are plotted. In the automated hybridization station, probe is injected at the top right of each slide (ii). In Array I, it is noted that the first point dips for every metacolumn, indicating that sub-grids on the left hand side of the slide had lower signal intensities than sub-grids on the right hand side of the slide. Similarly, the sub-grids at the bottom of the slide have lower signal intensity than sub-grids at the top of the slide. In Array 2, the pattern of differential hybridization from the top to the bottom of the slide still exists, but the positional effect is more subtle and therefore would not be detected by visualization of a slide without appropriate controls. These decreasing signal intensities may result from scanner output variables (e.g., photobleaching or optical focus as slide is scanned from top to bottom), in addition to differential hybridization. 


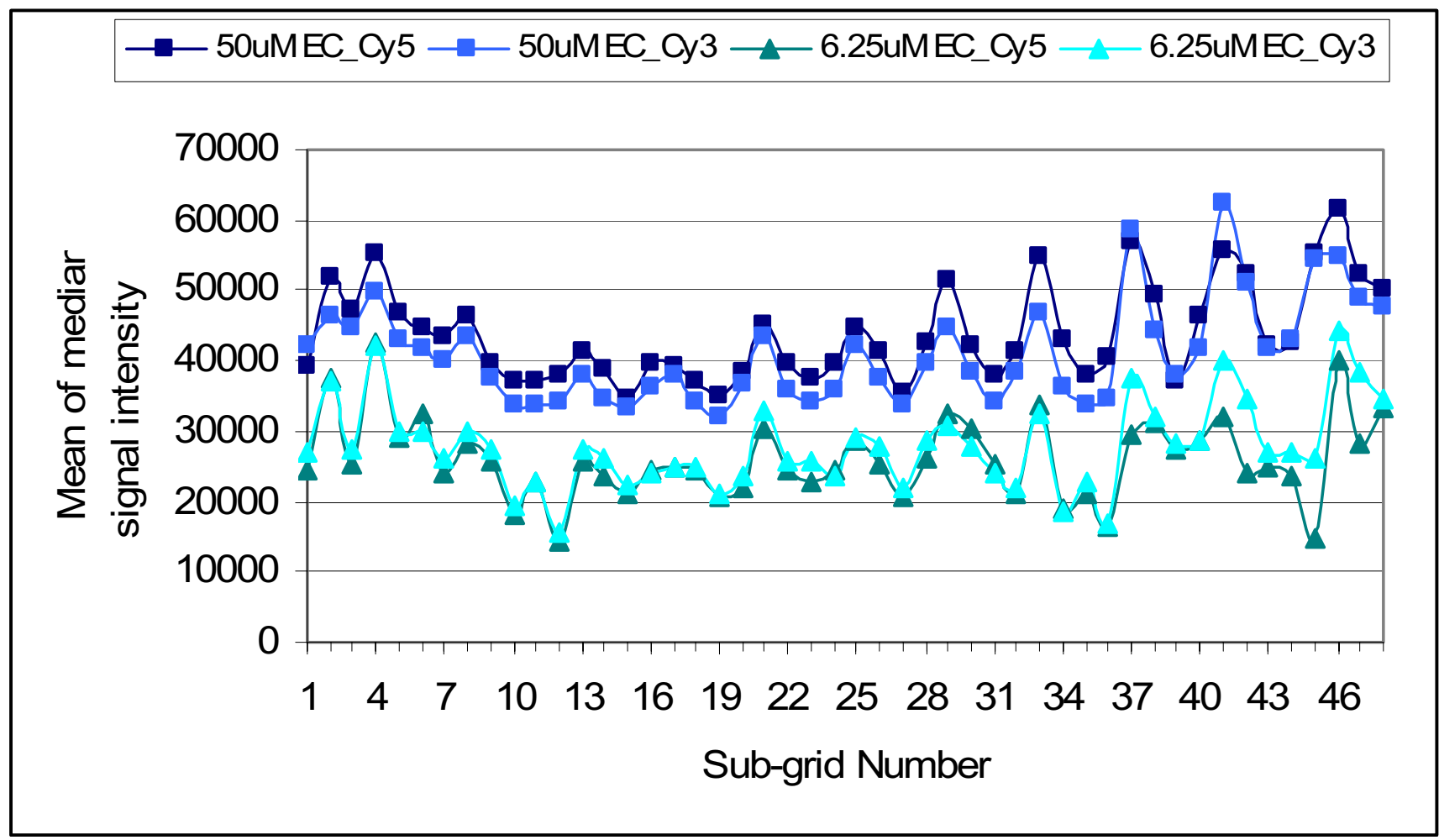

Figure 8

An example of a more typical EC positional hybridization pattern. The array data were derived from a hybridization reaction of one RNA sample included in the EC-normalization validation exercise summarized in Tables I-3. Cy5 (experiment) and Cy3 (reference) values are plotted for two EC spot concentrations (6.25 and $50 \mu \mathrm{M})$ across the 48 subgrids on the array and ordered as shown in Figure 7. A comparison of the average of the Cy5/Cy3 ratios of Grids \#10-28 with the combined average of Grids \# I-9 and I I -48 showed no significant difference (t-test, two-tailed, $\mathrm{p}=0.390$ and $p=0.393$ for 50 and $6.25 \mu \mathrm{M}$, respectively)

iment, one of the twelve printing pins had produced carryover effects (see previous section). Four of the 16 genes were located within the suspect print group; however, none of the four oligonucleotides were printed in positions likely to have been affected by carryover effects, such as locations following a differential gene or a gene with very high relative expression.

In a second analysis of the same data, using a standard LOWESS without incorporating the ECs, 39 genes were statistically significant $(\mathrm{p}<0.05)$ after a FDR adjustment based on the James-Stein estimator (Table 2). Between the two analyses, there were 24 genes that were in common (rows with bold text in Table 2), 11 genes specific to the EC-normalized analysis and 15 specific to the LOWESS normalized analysis (none were affected by carryover artifacts).

To select a sub-set of genes for RT-PCR analysis, microarray gene expression data normalized with $\mathrm{EC}$ and without EC (Tables 1, 2) were sorted according to the FDR adjusted P-values. A list of genes for each type of normalization was derived, in which $\mathrm{p}$-values less than 0.05 were recorded for the FDR adjusted overall treatment effect AND for one of the pairwise comparisons, comparing the treated samples to the control. The union of the two lists consisted of 27 probes, with a total of 31 pairwise comparisons. Two additional probes (Anpep, Cyp2a4; giving four additional pairwise comparisons) were also included, since earlier statistical calculations (1000 permutations with residual shuffling) had indicated both significant pairwise comparisons and overall effects, but these values were not confirmed in the analyses presented in Tables 1 and 2. Results from the microarrays for these 35 overall and pairwise comparisons plus the results from RT-PCR analyses for 27 of these comparisons are presented in Table 3.

The RT-PCR analyses included all 19 pairwise comparisons from the two microarray normalizations that gave conflicting conclusions on whether the respective 17 probes detected differentially expressed mRNAs (Table 3 ). 


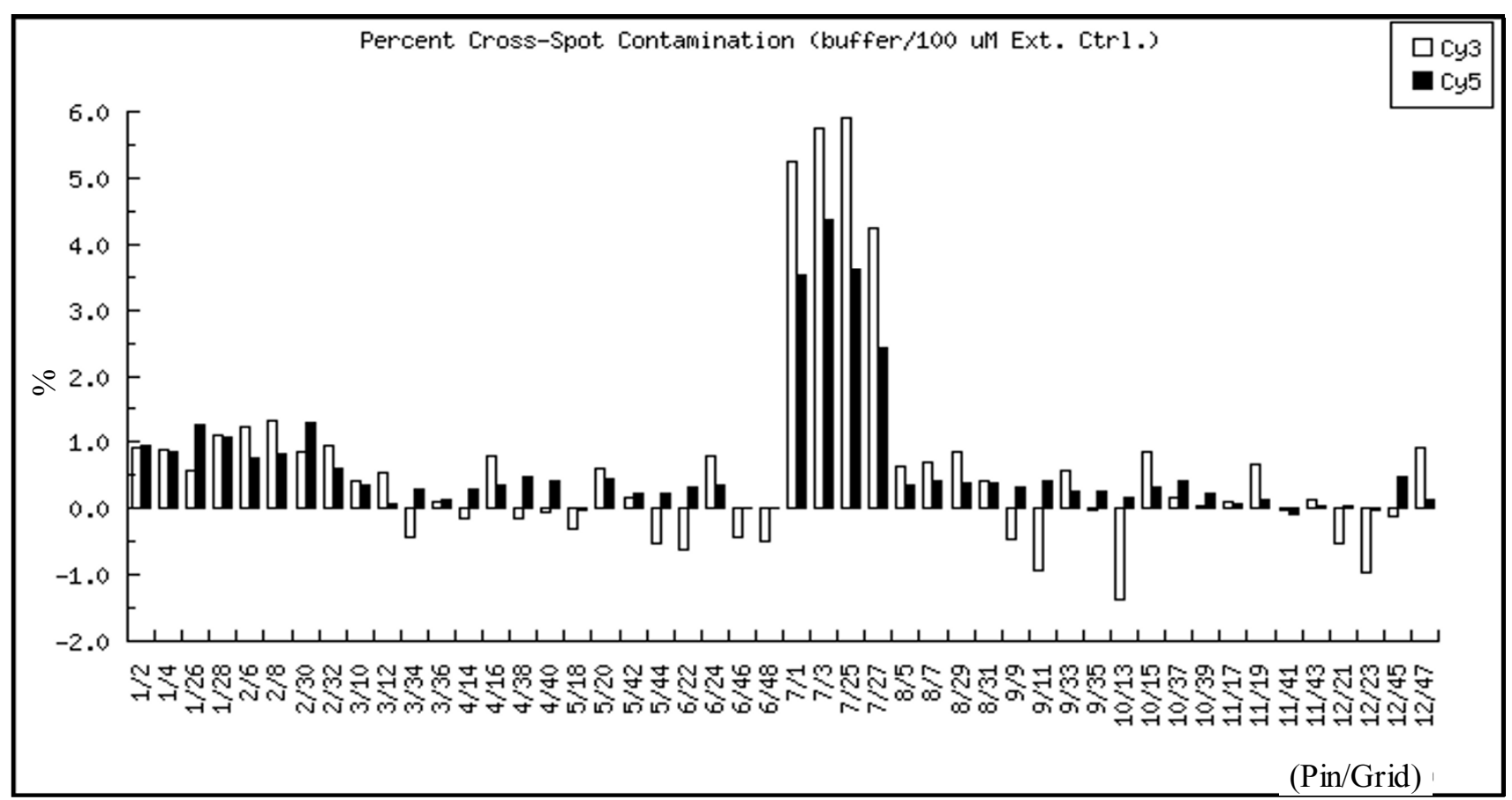

Figure 9

Detection of cross-spot contamination (in \%) per pin across a ToxArray ${ }^{\mathrm{TM}}$ slide. The slide was hybridized with Cy5-labeled mouse liver RNA and with Cy3-labeled Universal mouse reference RNA. The slide shows a high amount of cross-pin carryover from the $100 \mu \mathrm{M}$ EC oligonucleotide to the buffer spot in both the Cy3 and Cy5 channels. Cross-pin carry-over is noted in all sub-grids printed by pin 7.

Based on these 19 comparisons, the results from the normalization using the composite LOWESS (with EC) revealed 15 comparisons that were in agreement with the RT-PCR results, compared to 6 out of 19 based on the results from LOWESS normalized data. Additional RTPCR analyses were done using RNA samples which gave microarray results ( 6 probes with 8 pairwise comparisons) that were in agreement between the EC and without EC analyses (Table 3). All six microarray probe results were confirmed to be correct, although two pairwise comparisons for two of the probes conflicted with the RT-PCR results. Results from the RT-PCR were used to determine the true positives, false negatives, false positives and true negatives, and to calculate the sensitivity, specificity and the efficiency of the normalization methods (Tables 4 and 5 ). Using the EC series (composite normalization) yielded higher sensitivity, specificity and efficiency compared to not using the EC series for normalization, considering either all pairwise comparisons or just those in disagreement.

Two Chi-square contingency table analyses comparing the results from the RT-PCR and the results from both micro- array analyses were conducted. Only the 19 probes that were in disagreement between the two microarray results were included and a Yates correction (a continuity correction) was applied. The RT-PCR and the results from the composite LOWESS indicated an association with a pvalue of 0.0485 , whereas RT-PCR and the results from the LOWESS normalized data without the external controls showed no association ( $\mathrm{p}$-value $=0.2301$ ).

\section{Effect of Spot Replication on Detection of Differential Gene Expression using ToxArray ${ }^{\mathrm{TM}}$}

The effect of spot replication (spots arranged in 4 replicate supergrids, per array) on the power of ToxArray ${ }^{\mathrm{TM}}$ to detect differences in expression was estimated by conducting the EC-based and LOWESS-based normalizations, using one randomly chosen spot per array. The number of genes identified as significantly differentially expressed was reduced in the single-spot analysis to 13 and 16 genes revealed by EC and LOWESS normalization, respectively, compared to 35 and 39, respectively, by the 4-spot analysis. Only eight of the 24 genes identified in common in the 4-spot analysis were also identified in common in the single spot analyses (Cyp2b10, Cyp2b9, Gstm3, Gdf15, 
Table I: ToxArray ${ }^{\mathrm{TM}}$ data normalized using EC: Overall adjusted $\mathrm{p}$ after exposure to PB and fold changes (relative to Control) and pairwise $p$-values at each dose for each gene (probe) that showed differential expression.

\begin{tabular}{|c|c|c|c|c|c|c|c|c|c|}
\hline \multirow[b]{2}{*}{$\begin{array}{l}\text { Gene(probe) } \\
\text { Name> }\end{array}$} & \multirow[b]{2}{*}{ Full name } & \multirow[b]{2}{*}{ GenBank } & \multicolumn{2}{|c|}{$\begin{array}{l}\text { Control versus } \\
100 \mathrm{mg} / \mathrm{kg}\end{array}$} & \multicolumn{2}{|c|}{$\begin{array}{l}\text { Control versus } \\
10 \mathrm{mg} / \mathrm{kg}\end{array}$} & \multicolumn{2}{|c|}{$\begin{array}{l}\text { Control versus } \\
1 \mathrm{mg} / \mathrm{kg}\end{array}$} & \multirow{2}{*}{$\begin{array}{c}\text { James-Stein } \\
\text { F-Test }{ }^{\dagger} \\
\begin{array}{c}\text { Overall } \\
\text { P-value }\end{array}\end{array}$} \\
\hline & & & $\begin{array}{l}\text { Fold } \\
\text { change }\end{array}$ & $\begin{array}{l}\text { Pairwise } \\
\text { P-value }\end{array}$ & $\begin{array}{l}\text { Fold } \\
\text { change }\end{array}$ & $\begin{array}{l}\text { Pairwise } \\
\text { P-value }\end{array}$ & $\begin{array}{l}\text { Fold } \\
\text { change }\end{array}$ & $\begin{array}{l}\text { Pairwise } \\
\text { P-value }\end{array}$ & \\
\hline Сур2ь9 & $\begin{array}{l}\text { cytochrome } \mathrm{P} 450,2 \mathrm{~b} 9 \text {, } \\
\text { phenobarbitol inducible, type a, }\end{array}$ & NM 010000 & 8.29 & 0.0000 & 3.22 & 0.0000 & 1.16 & 0.8087 & 0.0000 \\
\hline Сур2b10 & $\begin{array}{l}\text { Cytochrome P450, } 2 \mathrm{bl0} \\
\text { phenobarbitol inducible, type b }\end{array}$ & NM 009998 & 5.10 & 0.0000 & 2.95 & 0.0000 & -1.08 & 0.8437 & 0.0000 \\
\hline Gdf। 5 & growth differentiation factor 15 & NM 011819 & 2.83 & 0.0000 & 1.25 & 0.3499 & 1.07 & 0.8667 & 0.0000 \\
\hline Gstm3 & $\begin{array}{l}\text { glutathione S- transferase mu } 3 \\
\text { (EC 2.5.1.18) }\end{array}$ & 103953 & 2.16 & 0.0000 & 1.04 & 0.8458 & 1.30 & 0.4200 & 0.0000 \\
\hline Lpin I & lipin I, alias fatty liver dystrophy & NM 015763 & -1.94 & 0.0009 & -1.18 & 0.3932 & -1.08 & 0.8437 & 0.0039 \\
\hline Gadd45b & $\begin{array}{l}\text { growth arrest and DNA-damage- } \\
\text { inducible } 45 \text { beta }\end{array}$ & NM 008655 & 1.92 & 0.0000 & 1.08 & 0.6595 & -1.13 & 0.7038 & 0.0000 \\
\hline Gadd45a & $\begin{array}{l}\text { growth arrest and DNA damage } \\
\text { inducible }\end{array}$ & NM 007836 & 1.66 & 0.0003 & 1.20 & 0.2245 & -1.24 & 0.4200 & 0.0000 \\
\hline Por & $\begin{array}{l}\text { NADPH cytochrome p450 } \\
\text { oxidoreductase }\end{array}$ & NM 008898 & 1.66 & 0.0806 & 1.22 & 0.3847 & 1.04 & 0.9392 & 0.0402 \\
\hline TiegI & $\begin{array}{l}\text { TGFB inducible early growth } \\
\text { response I }\end{array}$ & NM 013692 & -1.64 & 0.0011 & -1.23 & 0.1983 & -1.21 & 0.5440 & 0.0062 \\
\hline Gstm I & glutathione S-transferase mu I & NM 010358 & 1.63 & 0.2258 & -1.14 & 0.6339 & -1.03 & 0.9622 & 0.0377 \\
\hline sult lc2 & $\begin{array}{l}\text { sulfotransferase family IC, } \\
\text { member } 2\end{array}$ & NM 026935 & 1.55 & 0.0044 & 1.16 & 0.3501 & 1.21 & 0.5440 & 0.0350 \\
\hline AhR & rat Ah receptor & NM 013464 & 1.48 & 0.0423 & -1.05 & 0.7919 & -1.12 & 0.7389 & 0.0039 \\
\hline Chk & choline kinase & NM 013490 & -1.45 & 0.0041 & -1.31 & 0.0876 & 1.02 & 0.9443 & 0.0039 \\
\hline Adcy6 & adenylate cyclase 6 & NM 007405 & -1.43 & 0.0003 & -1.20 & 0.1165 & -1.05 & 0.7925 & 0.0004 \\
\hline Bhmt & $\begin{array}{l}\text { betaine homocysteine methyl } \\
\text { transferase }\end{array}$ & NM 016668 & -1.40 & 0.2598 & -1.16 & 0.4362 & 1.19 & 0.6392 & 0.0385 \\
\hline gstm2 & glutathione S-transferase, mu 2 & NM 008183 & 1.39 & 0.0313 & -1.10 & 0.4647 & -1.01 & 0.9754 & 0.0054 \\
\hline Dusp6 & dual specificity phosphatase 6 & NM 026268 & 1.39 & 0.0852 & 1.23 & 0.2007 & -1.07 & 0.8288 & 0.0181 \\
\hline Lbp & Lipopolysaccharide binding protein & NM 008489 & 1.39 & 0.0104 & 1.15 & 0.2591 & 1.32 & 0.1249 & 0.0379 \\
\hline Rbpl & retinol binding protein I, cellular & NM 011254 & 1.34 & 0.2364 & -1.19 & 0.2941 & 1.00 & 0.9976 & 0.0101 \\
\hline Ephxl & $\begin{array}{l}\text { epoxide hydrolase I, microsomal; } \\
\text { Eph I, Eph-I, AlI } 95553\end{array}$ & NM 010145 & 1.33 & 0.0486 & -1.08 & 0.5597 & 1.05 & 0.8358 & 0.0181 \\
\hline Gsta4 & Glutathione S-transferase, alpha 4 & NM 010357 & 1.32 & 0.1312 & -1.14 & 0.3506 & -1.10 & 0.7389 & 0.0045 \\
\hline Ube2b & $\begin{array}{l}\text { ubiquitin conjugating enzyme, E2B } \\
\text { (RAD } 6 \text { homoly S.cerevisea) }\end{array}$ & NM 009458 & -1.23 & 0.0358 & -1.01 & 0.8808 & 1.00 & 0.9935 & 0.0350 \\
\hline Copeb & $\begin{array}{l}\text { core promoter element binding } \\
\text { protein }\end{array}$ & NM 011803 & -1.21 & 0.8557 & -1.28 & 0.1810 & -1.44 & 0.1569 & 0.0471 \\
\hline Haol & hydroxyacid oxidase & NM 010403 & -1.20 & 0.8890 & 1.12 & $0.564 I$ & 1.38 & 0.4200 & 0.0402 \\
\hline Anpep & aminopeptidase $\mathrm{N}$ & NM 008486 & 1.20 & 0.4022 & -1.20 & 0.1456 & -1.05 & 0.8153 & 0.0070 \\
\hline Egfr & epidermal growth factor receptor & NM 007912 & -1.18 & 0.7714 & -1.04 & 0.7719 & 1.21 & 0.4200 & 0.0429 \\
\hline Gpam & $\begin{array}{l}\text { glycerol-3-phosphate } \\
\text { acyltransferase, mitochondrial }\end{array}$ & NM 008149 & -1.16 & 0.2258 & -1.00 & 0.9864 & 1.13 & 0.4200 & 0.0068 \\
\hline OlfrII6I & olfactory receptor 1161 & NM $\mid 46848$ & 1.13 & $0.847 \mid$ & 1.30 & 0.0420 & 1.27 & 0.1191 & 0.0300 \\
\hline Keap I & $\begin{array}{l}\text { Kelch-like ECH-assoc. protein I, } \\
\text { cytosolic inhibitor of NRF2) }\end{array}$ & NM 016679 & -1.12 & 0.8821 & -1.24 & 0.1165 & -1.38 & 0.0941 & 0.0181 \\
\hline Ssrpl & $\begin{array}{l}\text { Structure specific recognition } \\
\text { protein I }\end{array}$ & $\underline{X M|3027|}$ & -1.10 & 0.8932 & -1.13 & 0.3501 & -1.34 & 0.1191 & 0.0121 \\
\hline mpg & $\mathrm{N}$-methylpurine-DNA glycosylase & NM 010822 & 1.09 & 0.8894 & 1.30 & 0.0420 & 1.07 & 0.7269 & 0.0417 \\
\hline Ape2 & AP endonuclease 2 & NM 029943 & -1.04 & 0.9530 & -1.04 & 0.8232 & -1.37 & 0.3673 & 0.0385 \\
\hline Ripk I & $\begin{array}{l}\text { receptor (TNFRSF)-interacting } \\
\text { serine-threonine kinase I }\end{array}$ & NM 009068 & -1.03 & 0.9565 & -1.10 & 0.5255 & -1.43 & 0.1191 & 0.0490 \\
\hline Nme2 & $\begin{array}{l}\text { expressed in non-metastatic cells } 2 \text {, } \\
\text { protein }\end{array}$ & NM 008705 & 1.02 & 0.9737 & -1.24 & 0.2245 & -1.12 & 0.7406 & 0.0238 \\
\hline Vegfb(2) & vascular endothelial growth factor $B$ & NM 011697 & -1.00 & 0.9944 & -1.21 & 0.1279 & -1.32 & 0.1191 & 0.0080 \\
\hline
\end{tabular}

* Data ordered by fold-change in $100 \mathrm{mg} / \mathrm{ml}$ dose. There were no significant genes in $0.1 \mathrm{mg} / \mathrm{ml}$ dose. † Overall treatment effect 
Gadd45b, Gadd45a, Lpin1, Por). However, several other genes identified in common by the 4-spot analysis were partitioned into one of the two single-spot analyses: four of eight genes specific to the non-EC single-spot normalization (Gsta4, Rbp1, gstm2, Ephx1) and two of five genes specific to the single-spot EC normalization (Rbp1, AhR). Thus, approximately half of the genes found in common from the 4-spot analyses were found by either single spot analysis. Smaller proportions of genes specific to either normalization in the 4-spot analysis were found to be differential by the single spot analyses: 2/15 for non-EC (Gsta2 Ugt1a6) and 2/11 for EC (Keap1, Bhmt). One gene specific to the single-spot EC normalization and two genes specific to the single-spot non-EC normalization were not identified by the respective 4-spot analyses, reducing the proportion of genes found by the single spot analyses to 0.34 and 0.36 for EC and non-EC, respectively, in this comparison of spot replication effect.

\section{Discussion}

Appropriate quality controls and protocols for assessment of printing and hybridization in microarray experiments are crucial for ensuring high-quality data and establishing performance standards. Despite this, controls used for specifically addressing these issues are rarely reported in microarray publications. In addition, the development of features for normalization within, and between arrays is critical for all microarray applications, and is particularly relevant to the application of small focused arrays where a relatively large portion of the pathways may show changes in gene expression.

We developed an EC dilution series using the spike-in of a single Arabidopsis chlorophyll synthase gene hybridized to a series of dilutions of the complementary oligonucleotide printed on the microarray. In contrast with other external spike-in procedures that use a mixture of varying amounts of different control RNAs spiked into total RNA to derive signals across a range of intensities (e.g., [4]), our approach maintains a constant single input of external RNA, while varying the dilution of the EC oligonucleotide on the slide itself. This simple and flexible method allows a more robust quantitation of the spike-in compared to other methods. In addition, the EC series was designed to cover the full range of signal intensities (with no gaps) over the ToxArray ${ }^{\mathrm{TM}}$, reaching both background and saturated intensities (Figures 3, 4 and 5). The array incorporates a design that allows the use of the ECs, in combination with negative control spots, for detection of several technical problems that may arise in the printing, hybridization or scanning of a microarray, permitting correction or exclusion during subsequent analyses. Differential intensities of dye fluorescence on microarrays may arise from factors related to physical or chemical properties, differences in the efficiency of incorporation during probe synthesis and as a result of variations in scanner operation. These EC features can be applied in combination with LOWESS to normalize such systematic effects. Dye bias due to differential hybridization that, in part, may result from concentration-dependent effects within or between target cRNA populations and array spots that might arise during hybridization and washing procedures, may also be subject to this type of normalization. In this regard, it has been shown that tethered nucleic acid probes can behave differently depending on the nature of their supports [13], but here it was shown that the hybridization pattern derived from dilution of the EC oligonucleotide on the ToxArray ${ }^{\mathrm{TM}}$ slide surface was a close mimic of the pattern of hybridization resulting from similar dilutions of labeled cRNA in solution. A close relationship between these two concentration vs. intensity curves permits subsequent normalization adjustments of variations in murine cRNA hybridization intensity ratios, without introducing large errors. Composite LOWESS adjustments across the range of EC intensities on each array would be likely to represent similar differences in concentrationdependent hybridization amounts of murine genes, across samples.

Subtle unequal hybridization resulting in spatial patterning in dye fluorescence across an array might be undetected by visually examining the arrays, but may be revealed by the presence of increased variances of $\mathrm{Cy} 3 / \mathrm{Cy} 5$ ratios among the 48 EC replicates and four gene replicates of each grid. EC features might also be used to control positional and slide-to-slide hybridization effects that are more erratic, such as those resulting from exclusion by bubbles, by taking an average of the ECs within a subgrid, dividing each spot within the subgrid by the EC average, followed by multiplication of each spot by an overall slide average using the external controls. This would be done for each channel separately. Further refinements in normalization can be envisioned that would employ attributes of the EC hybridization curve, other than its average value. A systematic examination of these alternate approaches has not yet been made.

The limited sequence homology of the A. thaliana oligonucleotide among the genomes of organisms with published sequence information, suggests possible applications to gene expression studies in a wide variety of organisms. Since oligonucleotide probes designed with constraints on length, $\mathrm{G}+\mathrm{C} \%$ and secondary structure produce similar, parallel hybridization values over large cRNA concentration ranges [14], the choice of oligonucleotide used to produce an EC series in the manner we have described is not necessarily restricted to the sequence employed in the present experiments. 
The placement of negative control features within the ToxArray $^{\mathrm{TM}}$ design is an innovative approach to allow for the evaluation of cross-spot contamination during the printing process. Negative controls following either a saturated signal or a buffer spot were used to demonstrate the carryover of oligonucleotides within print-tip groups in a printrun (Figure 9) (this is a frequent problem in microarray printing that is rarely mentioned or quantified) [15]. Carry-over can significantly impact analysis of differential expression if low intensity spots are printed following spots that vary in intensity and occasionally show high signals. Similarly, carryover effects would degrade the usefulness of the EC series. Each print-run should be evaluated to ensure that this effect is minimized, especially with the (demonstrated) high fractional sensitivity of the Toxarray $^{\mathrm{TM}}(1 / 2,000,000$ transcripts). The knowledge of crossspot contamination could be incorporated into the selection of genes for RT-PCR confirmation and final analysis of differential gene expression, or print tip groups with unacceptable levels could be removed from the analysis.

Lastly, the ToxArray ${ }^{\mathrm{TM}}$ incorporates 4 replicates of each oligonucleotide spot distributed into separate subgrids on each slide. This degree and placement of spot replication can significantly increase the reliability of fluorescence measurements of gene expression levels $[11,16]$ and would thereby decrease variability of two-color ratios. Indeed, fewer genes were identified as differentially expressed based upon single oligonucleotide spots as compared to the four replicates in this study.

We exposed mice to a known hepatotoxin to test the hypothesis that global normalization approaches for focused microarrays will generate a higher proportion of false findings, relative to an approach using external features. Composite normalization incorporating the EC features (described in methods) resulted in a list of 36 genes with adjusted $\mathrm{p}$-values less than 0.05 . The predominant pathways represented among the genes that were differentially expressed included stress response, growth differentiation, apoptosis and xenobiotic metabolism. Among the latter, cyp2b10, cyp2b9, Gsta2 and Ephx1 were validated by RT-PCR. The induction of these pathways is consistent with the known pathologic effects of PB. This response was employed to provide confirmation, when verified by RT-PCR, that the composite normalization would score higher, as expected, on all measures of effectiveness, compared to the global normalization approach.

We expect the composite normalization to be even more superior in experiments where larger portions of genes are responsive. Although PB was an effective modifier of gene expression in this study of murine liver, only about 40 genes of the total 1600 on ToxArray ${ }^{\mathrm{TM}}$ might have been categorized by RT-PCR as significant responders, predicting from the existing microarray data and the observed frequencies of RT-PCR confirmation. This was a small proportion $(2.5 \%)$ of genes represented on the array. Increased numbers of responding genes might have been expected, given higher PB doses or a longer treatment period.

The relatively greater effectiveness of the EC composite normalization approach has also been found in a complementary study examining murine liver response to polychlorinated biphenyl exposure, in which 22 genes were validated using RT-PCR (data not shown - to be published elsewhere). The summary statistics presented in this study should be interpreted with care as there was some potential for selection bias in the choices made for RT-PCR validation among the genes identified as differential by both normalization procedures. However, we are currently carrying out additional RT-PCR experiments with other microarray datasets to achieve more representative estimates.

\section{Conclusion}

We demonstrate the application of a simple external control dilution series, in combination with a novel DNA array design, to yield improved detection of differential gene expression and provide quality control measures. The appropriate placement of controls and replication of probe spots allows for quantification of positional hybridization effects and cross-spot contamination. The application of a composite normalization, which incorporates an external control dilution series, results in an improvement in the sensitivity and predictivity of the test, as well as a minimization in false positive detection. Dilution of oligonucleotides on the microarray itself provides an innovative approach allowing the full dynamic range of the scanner to be covered with a single gene spike-in.

\section{Methods}

\section{ToxArray ${ }^{\mathrm{TM}}$ gene selection}

The list of ToxArray ${ }^{\mathrm{TM}}$ genes was compiled from our own data, as well as extensive information from published studies investigating gene expression changes, assessed using microarrays or other technologies, following toxicant exposures. Mouse genes (and homologues of rat and human genes) shown to be useful in toxicant-specific profiling were included $[4,17-19]$. Additionally, a large fraction of murine genes known to be involved in DNA repair, as well as the mouse cytochrome p450 family, were included. Our current list includes approximately 1600 genes known to respond to a wide range of toxic stressors. Approximately 50 housekeeping genes have been included on the array. Single-stranded 5'-C6 amino modified 70 mer oligonucleotide probes were designed and synthesized by Qiagen Inc (Alameda, CA, USA). 
Table 2: ToxArray ${ }^{\mathrm{TM}}$ data normalized without EC: Overall adjusted $\mathrm{p}$ after exposure to $\mathrm{PB}$ and fold changes (relative to Control) and pairwise $p$-values at each dose for each gene (probe) that showed differential expression. Bold text indicates genes identified as differential overall $(p<0.05)$ in the EC-normalized analysis $($ Table $I)$.

\begin{tabular}{|c|c|c|c|c|c|c|c|c|c|}
\hline \multirow[b]{2}{*}{$\begin{array}{l}\text { Gene } \\
\text { (probe) } \\
\text { Name }\end{array}$} & \multirow[b]{2}{*}{ Full name } & \multirow[b]{2}{*}{ GenBank } & \multicolumn{2}{|c|}{$\begin{array}{l}\text { Control versus } \\
100 \mathrm{mg} / \mathrm{kg}\end{array}$} & \multicolumn{2}{|c|}{$\begin{array}{l}\text { Control versus } \\
10 \mathrm{mg} / \mathrm{kg}\end{array}$} & \multicolumn{2}{|c|}{$\begin{array}{l}\text { Control versus } \\
\qquad \mathrm{mg} / \mathrm{kg}\end{array}$} & \multirow{2}{*}{$\begin{array}{c}\text { James-Stein } \\
\text { F-Test } \\
\begin{array}{c}\text { Overall } \\
\text { P-value }\end{array}\end{array}$} \\
\hline & & & $\begin{array}{c}\text { Fold } \\
\text { change }\end{array}$ & $\begin{array}{l}\text { Pairwise } \\
\text { P-value }\end{array}$ & $\begin{array}{c}\text { Fold } \\
\text { change }\end{array}$ & $\begin{array}{l}\text { Pairwise } \\
\text { P-value }\end{array}$ & $\begin{array}{l}\text { Fold } \\
\text { change }\end{array}$ & $\begin{array}{l}\text { Pairwise } \\
\text { P-value }\end{array}$ & \\
\hline Сур2b9* & $\begin{array}{l}\text { cytochrome } \mathrm{P450}, 2 \mathrm{~b} 9 \text {, } \\
\text { phenobarbitol inducible, type a, }\end{array}$ & NM 010000 & 8.55 & 0.0000 & 3.56 & 0.0000 & 1.15 & 0.8412 & 0.0000 \\
\hline Cyp2b10 & $\begin{array}{l}\text { Cytochrome } \mathrm{P} 450,2 \mathrm{blO} \\
\text { phenobarbitol inducible, type b }\end{array}$ & NM 009998 & 3.93 & 0.0000 & 2.92 & 0.0000 & -1.08 & 0.8501 & 0.0000 \\
\hline Gdf। 5 & growth differentiation factor 15 & NM 011819 & 2.57 & 0.0000 & 1.26 & 0.6381 & 1.11 & 0.8311 & 0.0002 \\
\hline Gsta2 & Glutathione S-transferase, alpha 2 (Yc2) & NM 008182 & 2.26 & 0.0353 & 1.08 & 0.9165 & -1.22 & 0.7337 & 0.0160 \\
\hline Gstm3 & $\begin{array}{l}\text { glutathione S- transferase mu } 3 \\
\text { (EC 2.5.1.18) }\end{array}$ & $\overline{03953}$ & 2.21 & 0.0000 & -1.01 & 0.9793 & 1.31 & 0.4323 & 0.0002 \\
\hline Gadd45b & $\begin{array}{l}\text { growth arrest and DNA-damage- } \\
\text { inducible } 45 \text { beta }\end{array}$ & NM 008655 & 1.93 & 0.0000 & 1.04 & 0.8931 & -1.12 & 0.6016 & 0.0000 \\
\hline Lpin I & lipin I, alias fatty liver dystrophy & NM 015763 & -1.66 & 0.0037 & -1.02 & 0.9469 & 1.03 & 0.9303 & 0.0051 \\
\hline Gadd45a & $\begin{array}{l}\text { growth arrest and DNA damage } \\
\text { inducible }\end{array}$ & NM 007836 & 1.62 & 0.0024 & 1.25 & 0.4642 & -1.22 & 0.4506 & 0.0000 \\
\hline Idil & isopentenyl-diphosphate delta isomerase & NM_145360 & -1.57 & 0.0131 & -1.44 & 0.2098 & -1.04 & 0.9206 & 0.0160 \\
\hline Por & $\begin{array}{l}\text { NADPH cytochrome p450 } \\
\text { oxidoreductase }\end{array}$ & NM 008898 & 1.55 & 0.0489 & 1.34 & 0.4157 & 1.07 & 0.8477 & 0.0341 \\
\hline Rbp I & retinol binding protein I, cellular & NM 011254 & 1.49 & 0.0029 & 1.04 & 0.8850 & 1.14 & 0.5150 & 0.0094 \\
\hline AhR & rat $\mathrm{Ah}$ receptor & NM 013464 & 1.42 & 0.0676 & 1.06 & 0.8713 & -1.07 & 0.8304 & 0.0436 \\
\hline Dusp6 & dual specificity phosphatase 6 & NM 026268 & 1.41 & 0.0486 & 1.29 & 0.3460 & -1.04 & 0.9018 & 0.0107 \\
\hline Gsta4 & Glutathione S-transferase, alpha 4 & NM 010357 & 1.41 & 0.0037 & -1.00 & 0.9961 & -1.09 & 0.6389 & 0.0006 \\
\hline gstm2 & glutathione S-transferase, mu 2 & NM 008183 & 1.40 & 0.0131 & 1.05 & 0.8594 & 1.07 & 0.7447 & 0.0329 \\
\hline EphxI & $\begin{array}{l}\text { epoxide hydrolase I, microsomal; } \\
\text { Eph I, Eph-I, AII } 95553\end{array}$ & NM 010145 & 1.39 & 0.0004 & 1.08 & 0.6873 & 1.11 & 0.4882 & 0.0021 \\
\hline Chk & choline kinase & NM 013490 & -1.39 & 0.0214 & -1.17 & 0.5202 & 1.03 & 0.9165 & 0.0223 \\
\hline Ugtla6 & $\begin{array}{l}\text { UDP glycosyltransferase I family, } \\
\text { polypeptide A6 }\end{array}$ & $\underline{X M \mid 35531}$ & 1.38 & 0.0019 & 1.22 & 0.2979 & 1.13 & 0.4624 & 0.0063 \\
\hline Lbp & Lipopolysaccharide binding protein & NM 008489 & 1.38 & 0.0254 & 1.12 & 0.6547 & 1.35 & 0.1677 & 0.0436 \\
\hline Adcy6 & adenylate cyclase 6 & NM 007405 & -1.34 & 0.0037 & -1.04 & 0.8511 & 1.01 & 0.9774 & 0.0068 \\
\hline Pitpn & phosphatidylinositol transfer protein & NM 008850 & 1.23 & 0.0000 & 1.07 & 0.4947 & 1.08 & 0.4311 & 0.0004 \\
\hline Olfr447 & olfactory receptor 447 & NM 146988 & -1.20 & 0.6328 & -1.19 & 0.4947 & 1.03 & 0.9112 & 0.0436 \\
\hline Anpep & aminopeptidase $\mathbf{N}$ & NM 008486 & 1.20 & 0.3851 & -1.14 & 0.5202 & -1.02 & 0.9253 & 0.0223 \\
\hline $\mathrm{cd} 8 \mathrm{~b}$ & CD8 antigen, beta chain & NM 009858 & -1.16 & 0.0158 & -1.07 & 0.5160 & -1.11 & 0.2616 & 0.0436 \\
\hline Сур2а4 & $\begin{array}{l}\text { Cytochrome P450, 2a4 } \\
\text { (phenobarbitol inducer }\end{array}$ & NM 009997 & 1.14 & $0.385 I$ & -1.07 & 0.6474 & -1.09 & 0.4999 & 0.0045 \\
\hline Mmp9: & matrix metalloproteinase 9 & NM 013599 & -1.14 & 0.0735 & -1.15 & 0.1425 & -1.16 & 0.1632 & 0.0305 \\
\hline Egfr & epidermal growth factor receptor & $\overline{N M 007912}$ & -1.13 & 0.9847 & 1.07 & 0.8206 & 1.30 & 0.1971 & 0.0192 \\
\hline Haol & hydroxyacid oxidase & NM 010403 & -1.12 & 0.9867 & 1.24 & 0.5202 & 1.42 & 0.1991 & 0.0233 \\
\hline Gpam & $\begin{array}{l}\text { glycerol-3-phosphate } \\
\text { acyltransferase, mitochondrial }\end{array}$ & NM 008149 & -1.10 & 0.9847 & 1.11 & 0.5202 & 1.20 & 0.1971 & 0.0063 \\
\hline Ape2 & AP endonuclease 2 & NM 029943 & -1.09 & 0.9867 & -1.18 & 0.5833 & -1.43 & 0.1677 & 0.0395 \\
\hline Acadvl & $\begin{array}{l}\text { acyl-Coenzyme A dehydrogenase, } \\
\text { very long chain }\end{array}$ & $\overline{N M 017366}$ & -1.07 & 0.9867 & 1.10 & 0.5887 & 1.18 & 0.2294 & 0.0436 \\
\hline $\begin{array}{l}\text { SCADfami } \\
\text { lyprotein }\end{array}$ & mRNA for SCAD family protein & A]296079 & -1.05 & 0.9890 & 1.02 & 0.9388 & 1.26 & 0.1971 & 0.0395 \\
\hline PERP & PERP, TP53 apoptosis effector & NM 022032 & -1.04 & 0.9890 & 1.06 & 0.7161 & 1.15 & 0.2892 & 0.0170 \\
\hline Acaa2 & $\begin{array}{l}\text { acetyl-Coenzyme A acyltransferase } 2 \text {, } \\
\text { mitochondrial }\end{array}$ & NM 177470 & -1.02 & 0.9984 & 1.11 & 0.5202 & 1.24 & 0.1632 & 0.0094 \\
\hline Vegfb(2) & vascular endothelial growth factor $B$ & NM 011697 & -1.02 & 0.9984 & -1.25 & 0.2731 & -1.31 & 0.1677 & 0.0101 \\
\hline Fads2 & fatty acid desaturase 2 & NM 019699 & -1.02 & 0.9984 & 1.22 & 0.3816 & 1.29 & 0.1902 & 0.0395 \\
\hline Nme2 & $\begin{array}{l}\text { expressed in non-metastatic cells } 2 \text {, } \\
\text { protein }\end{array}$ & $\overline{N M 008705}$ & 1.01 & 0.9984 & -1.21 & 0.4947 & -1.14 & 0.5423 & 0.0436 \\
\hline Pxmp3 & peroxisomal membrane protein 3 & NM 008994 & -1.01 & 0.9984 & 1.11 & 0.3446 & 1.14 & 0.1677 & 0.0242 \\
\hline Unc5h3 & $\begin{array}{l}\text { Unc5c:unc-5 homolog C (C. elegans), } \\
\text { rostral cerebellar malform. }\end{array}$ & NM 009472 & -1.00 & 0.9984 & -1.08 & 0.6381 & 1.03 & 0.8466 & 0.0475 \\
\hline
\end{tabular}

\footnotetext{
* Bolded text indicates genes also identified as differential in the EC-normalized analysis (Table I)
} 
Table 3: Real-time RT-PCR analysis of significant genes $(p<0.05)$ identified in microarray data normalized with and/or without EC dilution series.

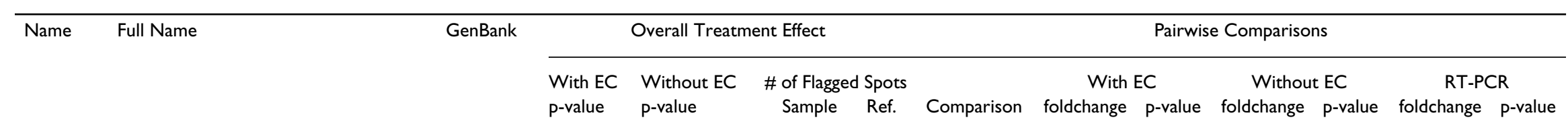

\section{Differentially expressed using both the EC and non-EC normalization}

\begin{tabular}{|c|c|c|c|c|c|c|c|c|c|c|c|c|c|}
\hline Adcy 6 & adenylate cyclase 6 & NM 007405 & 0.0004 & 0.0068 & 6 & 0 & 100 mg/kg & -1.43 & 0.0003 & -1.34 & 0.0037 & & \\
\hline Chk & choline kinase & NM 013490 & 0.0039 & 0.0223 & 1 & 0 & 100 mg/kg & -1.45 & 0.0041 & -1.39 & 0.0214 & -2.39 & 0.0122 \\
\hline Сур2b।0 & $\begin{array}{l}\text { Cytochrome P450, } 2 \mathrm{bl0} \\
\text { phenobarbitol inducible, type b }\end{array}$ & NM 009998 & 0.0000 & 0.0000 & 8 & 20 & 100 mg/kg & 5.10 & 0.0000 & 3.93 & 0.0000 & 3.76 & 0.0001 \\
\hline Сур2b10 & & NM 009998 & & & & & $10 \mathrm{mg} / \mathrm{kg}$ & 2.95 & 0.0000 & 2.92 & 0.0000 & 1.04 & 0.8600 \\
\hline Сур2ь9 & $\begin{array}{l}\text { cytochrome P450, 2b9, phenobarbitol } \\
\text { inducible, type a }\end{array}$ & NM 010000 & 0.0000 & 0.0000 & 15 & 22 & 100 mg/kg & 8.29 & 0.0000 & 8.55 & 0.0000 & 3.04 & 0.0965 \\
\hline Сур2ь9 & & NM 010000 & & & & & $10 \mathrm{mg} / \mathrm{kg}$ & 3.22 & 0.0000 & 3.56 & 0.0000 & 2.74 & 0.0052 \\
\hline EphxI & $\begin{array}{l}\text { epoxide hydrolase I, microsomal; } \\
\text { Eph I, Eph-I, All } 95553\end{array}$ & NM 010145 & 0.0181 & 0.0021 & 0 & 0 & 100 mg/kg & 1.33 & 0.0486 & 1.39 & 0.0004 & 1.46 & 0.0350 \\
\hline Gadd45a & $\begin{array}{l}\text { growth arrest and DNA damage } \\
\text { inducible }\end{array}$ & NM 007836 & 0.0000 & 0.0000 & 17 & 0 & $100 \mathrm{mg} / \mathrm{kg}$ & 1.66 & 0.0003 & 1.62 & 0.0024 & & \\
\hline Gadd45b & $\begin{array}{l}\text { growth arrest and DNA-damage- } \\
\text { inducible } 45 \text { beta }\end{array}$ & NM 008655 & 0.0000 & 0.0000 & 25 & I & 100 mg/kg & 1.92 & 0.0000 & 1.93 & 0.0000 & & \\
\hline GdfI5 & growth differentiation factor 15 & NM 011819 & 0.0000 & 0.0002 & 10 & I & $100 \mathrm{mg} / \mathrm{kg}$ & 2.83 & 0.0000 & 2.57 & 0.0000 & & \\
\hline gstm2 & glutathione S-transferase, mu 2 & NM 008183 & 0.0054 & 0.0002 & 0 & 0 & $100 \mathrm{mg} / \mathrm{kg}$ & 1.39 & 0.0313 & 1.40 & 0.0000 & 1.50 & 0.0013 \\
\hline Gstm3 & glutathione S-transferase, mu 3 & 103953 & 0.0000 & 0.0160 & 6 & 24 & 100 mg/kg & 2.16 & 0.0000 & 2.21 & 0.0131 & & \\
\hline Lbp & Lipopolysaccharide binding protein & NM 008489 & 0.0379 & 0.0051 & 1 & 25 & $100 \mathrm{mg} / \mathrm{kg}$ & 1.39 & 0.0104 & 1.38 & 0.0037 & 1.60 & 0.0345 \\
\hline Lpin I & lipin I & NM 015763 & 0.0039 & 0.0037 & 0 & 3 & 100 mg/kg & -1.94 & 0.0009 & -1.66 & 0.0037 & & \\
\hline
\end{tabular}

\section{Differentially expressed using EC normalization only}

\begin{tabular}{|c|c|c|c|c|c|c|c|c|c|c|c|c|c|}
\hline AhR & rat Ah receptor & NM 013464 & 0.0039 & 0.0436 & 0 & 0 & $100 \mathrm{mg} / \mathrm{kg}$ & 1.48 & 0.0423 & 1.42 & 0.0676 & 2.03 & 0.0003 \\
\hline Mpg & $\mathrm{N}$-methylpurine-DNA glycosylase & NM 010822 & 0.041698 & 0.3782 & 25 & 25 & $10 \mathrm{mg} / \mathrm{kg}$ & 1.30 & 0.0420 & 1.13 & 0.3911 & 1.42 & 0.0096 \\
\hline Olfrl16I & olfactory receptor I16I & NM 146848 & 0.03003 & 0.0800 & 25 & 25 & $10 \mathrm{mg} / \mathrm{kg}$ & 1.30 & 0.0420 & 1.12 & 0.3921 & 1.02 & 0.9618 \\
\hline sult Ic2 & sulfotransferase family IC, member 2 & NM 026935 & 0.0350 & 0.0572 & 18 & 25 & $100 \mathrm{mg} / \mathrm{kg}$ & 1.55 & 0.0044 & 1.56 & 0.0214 & 1.60 & 0.0161 \\
\hline
\end{tabular}


Table 3: Real-time RT-PCR analysis of significant genes $(p<0.05)$ identified in microarray data normalized with and/or without EC dilution series. (Continued)

\begin{tabular}{|c|c|c|c|c|c|c|c|c|c|c|c|c|c|}
\hline Tiegl & $\begin{array}{l}\text { TGFB inducible early growth } \\
\text { response I }\end{array}$ & NM 013692 & 0.0062 & 0.1318 & 0 & 0 & $100 \mathrm{mg} / \mathrm{kg}$ & -1.64 & 0.0011 & -1.45 & 0.0627 & -2.88 & 0.0008 \\
\hline Ube2b & ubiquitin conjugating enzyme & NM 009458 & 0.0350 & 0.0897 & 0 & 0 & $100 \mathrm{mg} / \mathrm{kg}$ & -1.23 & 0.0358 & -1.16 & 0.7402 & -1.56 & 0.0058 \\
\hline
\end{tabular}

Differentially expressed using non-EC normalization only

\begin{tabular}{|c|c|c|c|c|c|c|c|c|c|c|c|c|c|}
\hline $\mathrm{cd} 8 \mathrm{~b}$ & CD8 antigen, beta chain & NM 009858 & 0.2327 & 0.0436 & 25 & 25 & $100 \mathrm{mg} / \mathrm{kg}$ & -1.10 & 0.8557 & -1.16 & 0.0158 & 1.40 & 0.3272 \\
\hline Dusp6 & dual specificity phosphatase 6 & NM 026268 & 0.0181 & 0.0107 & 16 & 0 & 100 mg/kg & 1.39 & 0.0852 & 1.41 & 0.0486 & 1.40 & 0.0752 \\
\hline Gsta2 & $\begin{array}{l}\text { Glutathione S-transferase, alpha } 2 \\
\text { (Yc2) }\end{array}$ & NM 008182 & 0.0681 & 0.0160 & 0 & 0 & $100 \mathrm{mg} / \mathrm{kg}$ & 1.84 & 0.2849 & 2.26 & 0.0353 & 4.02 & 0.0026 \\
\hline Gsta4 & Glutathione S-transferase, alpha 4 & NM 010357 & 0.0045 & 0.0006 & 4 & 4 & $100 \mathrm{mg} / \mathrm{kg}$ & 1.32 & 0.1312 & 1.41 & 0.0037 & 1.20 & 0.2200 \\
\hline Idil & $\begin{array}{l}\text { isopentenyl-diphosphate delta } \\
\text { isomerase }\end{array}$ & NM 145360 & 0.0835 & 0.0436 & 0 & 0 & $100 \mathrm{mg} / \mathrm{kg}$ & -1.58 & 0.1234 & -1.57 & 0.0254 & -1.16 & 0.3523 \\
\hline Pitpn & phosphatidylinositol transfer protein & NM 008850 & 0.0969 & 0.0004 & 20 & 15 & 100 mg/kg & 1.24 & 0.0624 & 1.23 & 0.0000 & 1.07 & 0.3100 \\
\hline Por & $\begin{array}{l}\text { NADPH cytochrome p } 450 \\
\text { oxidoreductase }\end{array}$ & NM 008898 & 0.0402 & 0.0341 & 0 & 0 & $100 \mathrm{mg} / \mathrm{kg}$ & 1.66 & 0.0806 & 1.55 & 0.0489 & 1.45 & 0.0064 \\
\hline Rbpl & retinol binding protein I, cellular & $\underline{N M} 011254$ & 0.0101 & 0.0094 & 0 & 7 & $100 \mathrm{mg} / \mathrm{kg}$ & 1.34 & 0.2364 & 1.49 & 0.0029 & 1.13 & 0.3600 \\
\hline Ugtla6 & $\begin{array}{l}\text { UDP glycosyltransferase I family, } \\
\text { polypeptide A6 }\end{array}$ & $\underline{X M|3553|}$ & 0.0942 & 0.0063 & 0 & 0 & $100 \mathrm{mg} / \mathrm{kg}$ & 1.35 & 0.1044 & 1.38 & 0.0019 & -1.06 & 0.4810 \\
\hline
\end{tabular}

\section{Not differentially expressed}

\begin{tabular}{|c|c|c|c|c|c|c|c|c|c|c|c|c|c|}
\hline Anpep & aminopeptidase $\mathrm{N}$ & NM 008486 & 0.0070 & 0.0223 & 5 & 9 & $100 \mathrm{mg} / \mathrm{kg}$ & 1.20 & 0.4022 & 1.20 & 0.3851 & & \\
\hline Anpep & & NM 008486 & & & & & $10 \mathrm{mg} / \mathrm{kg}$ & -1.20 & 0.1456 & -1.14 & 0.9253 & -1.04 & 0.6932 \\
\hline Сур2а4 & $\begin{array}{l}\text { Cytochrome P450, 2a4 } \\
\text { (phenobarbitol inducer) }\end{array}$ & NM 009997 & 0.0818 & 0.0045 & 24 & 24 & $100 \mathrm{mg} / \mathrm{kg}$ & 1.19 & 0.2364 & 1.14 & 0.3851 & & \\
\hline Сур2а4 & & NM 009997 & & & & & $10 \mathrm{mg} / \mathrm{kg}$ & 1.12 & 0.2511 & -1.07 & 0.4999 & 1.32 & 0.0789 \\
\hline mpg & N-methylpurine-DNA glycosylase & NM 010822 & 0.0417 & 0.3782 & 25 & 25 & $100 \mathrm{mg} / \mathrm{kg}$ & 1.09 & 0.8894 & 1.03 & 0.9890 & -1.15 & 0.1757 \\
\hline OlfrII6I & olfactory receptor II6I & NM $\mid 46848$ & 0.0300 & 0.0800 & 25 & 25 & $100 \mathrm{mg} / \mathrm{kg}$ & 1.13 & 0.8471 & 1.06 & 0.9867 & -2.87 & 0.0386 \\
\hline
\end{tabular}


Table 4: Criteria for determination of the true positives (TP), false negatives (FN), false positives (FP) and true negatives (TN) for the microarray results.

\begin{tabular}{lcc}
\hline & Positive & Microarray Result using the Fs-test \\
& Negative \\
\hline Overall Treatment Effect & FDR p-value $<0.05$ & FDR P-value $>0.05$ \\
OR & FDR P-value $>0.05$ \\
Pairwise Comparison with Control* & AND & FN \\
RT PCR Result & FDR P-value $<0.05$ & TN \\
P-value $<0.05$ (differentially expressed) & TP & FP \\
P-value $>0.05$ (no change) & FP & \\
\hline
\end{tabular}

* comparison of individual doses against the control

\section{ToxArray ${ }^{\mathrm{TM}}$ Design}

The ToxArray ${ }^{\mathrm{TM}}$ consists of 12 sub-grids $(16$ rows $\times 12$ columns) printed in quadruplicate (for a total of 48 subgrids). External control (EC) normalization features are present in every sub-grid and consist of a series of 18 dilutions of a single probe corresponding to the Arabidopsis thaliana chlorophyll synthase gene (RefSeq NM_115041). The dilution series of the probe is prepared in ArraylT spotting solution (Telechem International, Sunnyvale,
CA, USA) (concentrations range from $0.000015 \mu \mathrm{M}$ to $100 \mu \mathrm{M}$ ). Each EC probe dilution is printed at least twice per sub-grid (42 EC features per sub-grid) for a total of more than $2000 \mathrm{EC}$ features across the space of the entire array. Each sub-grid also contains three types of negative controls including: buffer-only spots, randomized pools of non-specific 70 mer oligonucleotides (Qiagen Inc.; validated to ensure that they do not match any known mouse genes), and random hexamers (Qiagen, Inc.) in ArrayIT

Table 5: Measures of performance of microarray findings using normalization incorporating the external control features, compared to not incorporating the external control features.

\begin{tabular}{|c|c|c|c|c|}
\hline \multicolumn{5}{|c|}{ A. Using all microarray pairwise comparisons } \\
\hline \multirow[b]{2}{*}{ RT-PCR result: } & \multicolumn{2}{|c|}{ Microarray result using EC Normalization } & \multicolumn{2}{|c|}{ Microarray result NOT using EC normalization } \\
\hline & Significant & Not Significant & Significant & Not Significant \\
\hline Significant & II a & $3^{\mathrm{b}}$ & $8^{a}$ & $9 b$ \\
\hline Not Significant & $3^{c}$ & $10^{d}$ & $6^{c}$ & $4^{d}$ \\
\hline Sensitivity & \multicolumn{2}{|c|}{$78.6 \%$} & \multicolumn{2}{|c|}{$57.1 \%$} \\
\hline Specificity & \multicolumn{2}{|c|}{$76.9 \%$} & \multicolumn{2}{|c|}{$30.8 \%$} \\
\hline Positive Predictive Value & \multicolumn{2}{|c|}{$78.6 \%$} & \multicolumn{2}{|c|}{$47.1 \%$} \\
\hline Negative Predictive Value & \multicolumn{2}{|c|}{$76.9 \%$} & \multicolumn{2}{|c|}{$40.0 \%$} \\
\hline Efficiency of the test & \multicolumn{2}{|c|}{$77.8 \%$} & \multicolumn{2}{|c|}{$44.4 \%$} \\
\hline
\end{tabular}

B. Using microarray pairwise comparisons that were in disagreement

\begin{tabular}{|c|c|c|c|c|}
\hline \multirow[b]{2}{*}{ RT-PCR result: } & \multicolumn{2}{|c|}{ Microarray result using EC Normalization } & \multicolumn{2}{|c|}{ Microarray result NOT using EC normalization } \\
\hline & Significant & Not Significant & Significant & Not Significant \\
\hline Significant & 5 a & lb & $2^{\mathrm{a}}$ & $7^{b}$ \\
\hline Not Significant & $3^{c}$ & $10^{d}$ & 6c & $4^{d}$ \\
\hline Sensitivity & \multicolumn{2}{|c|}{$62.5 \%$} & \multicolumn{2}{|c|}{$25.0 \%$} \\
\hline Specificity & \multicolumn{2}{|c|}{$90.9 \%$} & \multicolumn{2}{|c|}{$36.4 \%$} \\
\hline Positive Predictive Value & \multicolumn{2}{|c|}{$83.3 \%$} & \multicolumn{2}{|c|}{$22.2 \%$} \\
\hline Negative Predictive Value & \multicolumn{2}{|c|}{$76.9 \%$} & \multicolumn{2}{|c|}{$40.0 \%$} \\
\hline Efficiency of the test & \multicolumn{2}{|c|}{$79.0 \%$} & \multicolumn{2}{|c|}{$31.6 \%$} \\
\hline
\end{tabular}

Sensitivity= TP/(TP+FN); Specificity = TN/(TN+FP); Pos. Predictive Value= TP/(TP+FP); Neg. Predictive Value = TN $/(T N+F N) ;$ Efficiency = $(\mathrm{TP}+\mathrm{TN}) /(\mathrm{TP}+\mathrm{TN}+\mathrm{FP}+\mathrm{FN})$.

a True Positive; b False Negative; c False Positive; d True Negative 
buffer (Figure 1). The latter two negative controls are useful to detect background resulting from fluorescence signal from oligonucleotides or random non-specific binding. Within each sub-grid, placement of one buffer control (Spots C; Figure 1) immediately follows the printing of a $100 \mu \mathrm{M}$ EC oligonucleotide (Spots B; Figure 1). The $100 \mu \mathrm{M}$ signal reaches saturation; juxtaposition of the buffer control spot immediately following the saturated control allows the calculation of cross-spot contamination, or carry-over of oligonucleotides across individual spots by the printing pin. Cross-spot contamination was evaluated by comparing the signal from spots $\mathrm{C}$, to a buffer-only spot within the same sub-grid that is printed immediately following another buffer-only spot (Spot A; Figure 1).

A 70 mer oligonucleotide probe was designed and synthesized for the Arabidopsis thaliana chlorophyll synthase gene (At3g51820; RefSeq NM_115041) (Qiagen Inc., Alameda, CA, USA). A. thaliana chlorophyll synthase RNA was produced through in vitro transcription of a plasmid provided by the University Health Network Microarray Centre (Toronto, ON, CA) (the plasmid contains a fragment of the A. thaliana chlorophyll synthase gene) using the T7 RiboMAX ${ }^{\mathrm{Tm}}$ Express Large Scale RNA Production System according to manufacturers protocol (Promega Corporation, Madison, WI, USA). In vitro transcribed RNA was quantified by UV light absorbance and visualized for transcript integrity by gel electrophoresis.

\section{ToxArray ${ }^{\mathrm{TM}}$ Production}

Oligonucleotides were diluted in ArrayIT Spotting Solution (Telechem International) to $40 \mu \mathrm{M}$ and printed onto PowerMatrix slides (Full Moon Biosystems, Sunnyvale, CA, USA) with the ChipWriter Pro robotic arrayer (BioRad Laboratories, Mississauga, ON, CA) at 65\% relative humidity. Printing pins were washed in water, dried, and sonicated in water three times between each pin loading. Following printing, slides were placed in a humid chamber, containing saturated sodium chloride solution, with a relative humidity of $65-75 \%$ for $10-14$ hours. Slides were air dried at room temperature for 30 minutes. Prior to hybridization slides were pretreated according to manufacturer's protocol (Full Moon Biosystems). Briefly, slides were incubated at room temperature in $0.2 \mathrm{X}$ SSC solution containing $0.2 \%$ SDS and $0.1 \%$ BSA, preheated to $55^{\circ} \mathrm{C}$ for $15-30$ minutes on an orbital shaker, rinsed thoroughly in Milli-Q water, and dried by centrifugation at $500 \mathrm{rpm}$ for 5 minutes.

\section{Animal Treatment}

Male B6C3F1 mice (age 27-35 days) obtained from Charles River were allowed food and water ad libitum. The animals were housed in individual cages under a $12 \mathrm{hr}$ light/12 hr dark lighting schedule, constant temperature and humidity, and provided with an enriched environment. Animals were acclimatized for at least 2 weeks. Treatment groups consisted of 5 animals dosed by oral gavage with $100,10,1$ or $0.1 \mathrm{mg} / \mathrm{kg}$ Phenobarbital (PB) (CAS: $57-30-7$ ) or $0.9 \%$ saline (vehicle control group) for 3 consecutive days. Animals were sacrificed four hours after the last PB exposure. Animals were anesthetized with $\mathrm{CO}_{2}, 0.5-0.7 \mathrm{~mL}$ of blood was collected by cardiac puncture, and animals were sacrificed by cervical dislocation. Liver was removed, flash-frozen in liquid nitrogen, and stored at $-80^{\circ} \mathrm{C}$ for further analyses. All animal care and handling were in accordance with Canadian Council for Animal Care Guidelines and were reviewed by the Health Canada Animal Care Committee prior to the start of the study.

\section{RNA isolation}

Total RNA from mouse liver was isolated using Trizol Reagent (Gibco-BRL, Life Technologies, Gaithersburg, Maryland, USA) according to the manufacturer's protocol. Briefly, $1 \mathrm{~mL}$ of Trizol reagent was added per 50-100 mg tissue and homogenized. Homogenized samples were incubated for 5 minutes at room temperature; chloroform was added at $0.2 \mathrm{~mL}$ per $1 \mathrm{~mL}$ Trizol reagent, mixed by inversion and incubated for 3 minutes. The aqueous phase was separated by centrifugation, and RNA was precipitated by the addition of isopropanol at $0.5 \mathrm{~mL}$ per 1 $\mathrm{mL}$ Trizol reagent and incubation for 10 minutes at room temperature. RNA was washed in $75 \%$ ethanol and re-dissolved in $1 \mu \mathrm{L}$ nuclease-free water per $1 \mathrm{mg}$ of tissue. Total RNA was further purified using the RNeasy Mini Kit (Qiagen Inc.) according to the manufacturer's protocol. RNA quality and quantity was assessed by UV spectrophotometry and 28S:18S ratios obtained by Agilent 2100 bioanalyzer (Agilent Technologies, Palo Alto, CA, USA).

\section{Preparation of labeled cRNA}

Labeled cRNA was prepared using the Low Input Fluorescent Linear Amplification Kit from Agilent Technologies according to manufacturer's protocol. For analysis of differential expression following $\mathrm{PB}$ exposures, $5 \mathrm{ng}$ of EC RNA was spiked into $5 \mu \mathrm{g}$ of liver RNA sample and mouse reference RNA (Stratagene, La Jolla, CA, USA). RNA was converted to cDNA using oligo dT-T7 promoter primer and random hexamers. Following second strand cDNA synthesis, cDNA was converted to cRNA and amplified by T7 RNA polymerase in the presence of Cy5- (liver cDNA) or Cy3-CTP (reference cDNA). The amplified cRNA product was purified using the RNeasy Mini Kit (Qiagen, Inc.), re-suspended in nuclease-free water, and quantified by UV spectrophotometry.

\section{Automated Hybridization Protocol}

Automated microarray hybridizations were carried out in an HS 4800 hybridization station (TECAN, Research Tri- 
angle Park, NC, USA). Microarrays were pre-washed two times $\left(50^{\circ} \mathrm{C}, 30\right.$ minutes; $0.2 \times$ SSC, $0.2 \%$ SDS, $0.1 \%$ BSA). Fifteen $\mu \mathrm{g}$ of labeled Cy 5 and Cy 3 cRNA probe was fragmented in $25 \times$ fragmentation buffer (Agilent In situ hybridization kit-plus, Agilent Technologies) at $60^{\circ} \mathrm{C}$ for 30 minutes. Fragmented cRNA was mixed with $2 \times$ hybridization buffer (Agilent In situ hybridization kit-plus) and hybridized on the ToxArray ${ }^{\mathrm{TM}}$ chips at $60^{\circ} \mathrm{C}$ for $17 \mathrm{~h}$. Chips were washed with $6 \times$ SSC, $0.005 \%$ Triton X-102 at $50^{\circ} \mathrm{C}$ for $10 \mathrm{~min}$, with $0.1 \times \mathrm{SSC}, 0.005 \%$ Triton $\mathrm{X}-102$ at room temperature for $15 \mathrm{~min}$, and rinsed with $0.06 \times$ SSC. Microarrays were dried by centrifugation at $500 \mathrm{rpm}$ for 5 minutes. For PB experiments, sample RNA was labeled with Cy5 and Universal mouse RNA was labeled with Cy3 and the automated procedure was used for hybridization and washing of all slides.

\section{Real time PCR}

RT-PCR was used to confirm differential gene expression of transcripts from microarray analyses. Reverse transcription was carried out in a $100 \mu$ l reaction mix with SuperScript II (Invitrogen, Burlington, ON, CA) using $1 \mu \mathrm{g}$ total RNA per animal. Quantitative PCR was performed with an iCycler IQ real-time detection system (BioRad Laboratories) using SYBR-Green. Using $1 \mu$ l reverse transcription solution and gene-specific primers (Qiagen, Mississauga, ON, Canada), PCR was performed in a $25 \mu$ l reaction Supermix (BioRad Laboratories). Primers were designed using Beacon design 2.0 (Premier BioSoft International, CA, USA) and sequences are available upon request. PCR reactions for each RNA species were performed in duplicate within a single plate, and the values of threshold cycle were averaged. Gene expression levels were normalized to $\beta 2$-microglobulin, which was found to be stable on the DNA microarrays. PCR efficiency was examined using the standard curve for each gene, determined from reactions that were included in wells of the respective plate. Primer specificity was assured by the melting curve for each gene. A $t$-test was used for statistical evaluation.

\section{Image analysis and statistics}

Arrays were scanned on a ScanArray Express (Perkin Elmer Life Sciences, Woodbridge, ON, Canada). To optimize the dynamic range of microarrays and allow the quantification of both high and low copy expressed genes, the same arrays were scanned using different photomultiplier settings allowing selection of images with saturated image intensities on the 50 and $100 \mu \mathrm{M}$ EC spots and on oligonucleotide spots for high-abundance genes such as Rpl5. Raw pixel intensities were derived in ImaGene 5.6 (BioDiscovery, Los Angeles, CA) and median signal intensities (not background subtracted) were used for subsequent analyses. Obtained data conformed to the suggested average $[\log 2(\mathrm{Cy} 3 * \mathrm{Cy} 5) / 2$ of 10 to 12 (1024 to 4096 RFUs) [20]. Data is available through ArrayExpress [21]. Present calls were determined as signals that were greater than the mean of the random 70 mer oligonucleotide negative controls plus three times the standard deviation (signals within the range of three standard deviations were flagged). Data from all samples were read into SAS 8.2 (SAS Institute Inc, Cary, NC, USA). The data were normalized using the composite LOWESS method [8] which takes a weighted average from a LOWESS fit using only the ECs with a span of 0.3, and a second LOWESS fit for each of the 12 print-tip groups with a span of 0.5 . Technical replicates on arrays were collapsed by use of the median normalized relative intensity. For comparison, a second normalization was carried out on PB samples using a LOWESS with a smooth span of 0.4 without incorporation of ECs. The MAANOVA 2.0 [22] library in R was used for graphical displays and analysis. Ratio-intensity plots for each array were obtained. Higher-level statistical analysis, including detection of differential expression was also conducted using MAANOVA methodology $[1,23]$.

\section{List of Abbreviations}

EC: External Control

PB: Phenobarbital

LOWESS: Locally Weighted Scatterplot Smoother

RT-PCR: reverse transcription - polymerase chain reaction

\section{Authors' contributions}

The concept of the ToxArray ${ }^{\mathrm{TM}}$ was CLY's. CLY, SB and CLP developed the external control series and the printing design. CLY designed and co-ordinated the PB experiment and drafted the manuscript. SB and CLY curated the original ToxArray ${ }^{\mathrm{TM}}$ gene list. SB managed the oligonucleotide library, developed QC/QA approaches, worked on the first draft of the manuscript and participated in the technical variability experiment. GZ \& CLP optimized the printing and hybridization of the ToxArray ${ }^{\mathrm{TM}}$, printed all arrays used, designed and conducted validation experiments for the on-slide dilution series, determined the fractional sensitivity of the array and modified the draft manuscript. MLB performed the technical variability experiment and image analysis. AW carried out all statistical analysis and experimental design for microarray experiments. JLZ carried out the PB animal experiment and the microarray analysis of the PB experiment as well as the RTPCR. AR managed and designed oligonucleotides for the ToxArray $^{\mathrm{TM}}$ and participated in the design of the ToxArray $^{\mathrm{TM}}$. HD conducted experiments to optimize the ToxArray $^{\mathrm{TM}}$ printing and hybridization. IBL contributed to the gene list and manuscript writing, supervised and advised SB. GRD participated in the design and coordination of the work, made contributions to the manuscripts and was the overall team leader. CLP and CLY were the project 
leaders. All authors have read and approved the final manuscript.

\section{Acknowledgements}

We would like to acknowledge the tireless efforts of R. Gagne in helping to maintain our data management system, our HC, EPA and University colleagues for contributing to the gene list, and Aris Polyzos, Leonora Marro and William Ross for helpful discussions and comments on the manuscript. This work was funded by the Health Canada Genomics R\&D fund. Note added in proof: Health Canada currently has patent applications pending on this technology. The authors would also like to acknowledge funding provided by the Canadian Regulatory System for Biotechnology.

\section{References}

I. Kerr MK, Churchill GA: Statistical design and the analysis of gene expression microarray data. Genet Res 200I, 77: I23-128.

2. Park T, Yi SG, Kang SH, Lee S, Lee YS, Simon R: Evaluation of normalization methods for microarray data. BMC Bioinformatics 2003, 4:33.

3. Chen YJ, Kodell R, Sistare F, Thompson KL, Morris S, Chen JJ: Normalization methods for analysis of microarray gene-expression data. I Biopharm Stat 2003, I 3:57-74.

4. van de Peppel J, Kemmeren P, van Bakel H, Radonjic M, van Leenen $D$, Holstege FC: Monitoring global messenger RNA changes in externally controlled microarray experiments. EMBO Rep 2003, 4:387-393.

5. Khimani AH, Mhashilkar AM, Mikulskis A, O'Malley M, Liao J, Golenko EE, Mayer P, Chada S, Killian JB, Lott ST: Housekeeping genes in cancer: normalization of array data. Biotechniques 2005, 38:739-745.

6. Neuvians TP, Gashaw I, Sauer CG, von Ostau C, Kliesch S, Bergmann M, Hacker A, Grobholz R: Standardization strategy for quantitative PCR in human seminoma and normal testis. J Biotechnol 2005, II7:|63-I7I.

7. Fluck M, Dapp C, Schmutz S, Wit E, Hoppeler H: Transcriptional profiling of tissue plasticity: role of shifts in gene expression and technical limitations. J Appl Physiol 2005, 99:397-4I3.

8. Yang YH, Dudoit S, Luu P, Lin DM, Peng V, Ngai J, Speed TP: Normalization for CDNA microarray data: a robust composite method addressing single and multiple slide systematic variation. Nucleic Acids Res 2002, 30:e I 5.

9. Lee PD, Sladek R, Greenwood CM, Hudson TJ: Control genes and variability: absence of ubiquitous reference transcripts in diverse mammalian expression studies. Genome Res 2002, 1 2:292-297.

10. Yang IV, Chen E, Hasseman JP, Liang W, Frank BC, Wang S, Sharov V, Saeed Al, White J, Li J, Lee NH, Yeatman TJ, Quackenbush J: Within the fold: assessing differential expression measures and reproducibility in microarray assays. Genome Biol 2002, 3:research0062.

II. Ramakrishnan R, Dorris D, Lublinsky A, Nguyen A, Domanus M, Prokhorova A, Gieser L, Touma E, Lockner R, Tata M, Zhu X, Patterson M, Shippy R, Sendera TJ, Mazumder A: An assessment of Motorola CodeLink microarray performance for gene expression profiling applications. Nucleic Acids Res 2002, 30:e30.

12. Cui X, Hwang JT, Qiu J, Blades NJ, Churchill GA: Improved statistical tests for differential gene expression by shrinking variance components estimates. Biostatistics 2005, 6:59-75.

13. Southern E, Mir K, Shchepinov M: Molecular interactions on microarrays. Nat Genet 1999, $21: 5-9$.

14. Dorris DR, Nguyen A, Gieser L, Lockner R, Lublinsky A, Patterson M, Touma E, Sendera TJ, Elghanian R, Mazumder A: Oligodeoxyribonucleotide probe accessibility on a three-dimensional DNA microarray surface and the effect of hybridization time on the accuracy of expression ratios. BMC Biotechnol 2003, 3:6.

15. Wilson AC, Dunbar HE, Davis GK, Hunter WB, Stern DL, Moran NA: A dual-genome microarray for the pea aphid, Acyrthosiphon pisum, and its obligate bacterial symbiont, Buchnera aphidicola. BMC Genomics 2006, 7:50.

16. Lee ML, Kuo FC, Whitmore GA, Sklar J: Importance of replication in microarray gene expression studies: statistical meth- ods and evidence from repetitive cDNA hybridizations. Proc Natl Acad Sci U S A 2000, 97:9834-9839.

17. Hamadeh HK, Bushel PR, Jayadev S, Martin K, DiSorbo O, Sieber S, Bennett L, Tennant R, Stoll R, Barrett JC, Blanchard K, Paules RS, Afshari CA: Gene expression analysis reveals chemical-specific profiles. Toxicol Sci 2002, 67:219-231.

18. Thomas RS, Rank DR, Penn SG, Craven MW, Drinkwater NR, Bradfield CA: Developing toxicologically predictive gene sets using cDNA microarrays and Bayesian classification. Methods Enzymol 2002, 357:198-205.

19. Ellinger-Ziegelbauer H, Stuart B, Wahle B, Bomann W, Ahr HJ: Comparison of the expression profiles induced by genotoxic and nongenotoxic carcinogens in rat liver. Mutat Res 2005, 575:6I-84.

20. Sharov V, Kwong KY, Frank B, Chen E, Hasseman J, Gaspard R, Yu Y, Yang I, Quackenbush J: The limits of log-ratios. BMC Biotechnol 2004, 4:3.

21. http://www.ebi.ac.uk/arrayexpress/: accession number E-MEXP525.

22. Wu H, Kerr K, Cui X, Churchill GA: MAANOVA: A software package for the analysis of spotted CDNA microarray experiments. In The analysis of gene expression data: methods and software Edited by: Pargmigiani G, Garrett E, Irizarry R and Zeger S. New York, Springer; 2002.

23. Kerr MK, Martin M, Churchill GA: Analysis of variance for gene expression microarray data. J Comput Biol 2000, 7:819-837.
Publish with Biomed Central and every scientist can read your work free of charge

"BioMed Central will be the most significant development for disseminating the results of biomedical research in our lifetime. "

Sir Paul Nurse, Cancer Research UK

Your research papers will be:

- available free of charge to the entire biomedical community

- peer reviewed and published immediately upon acceptance

- cited in PubMed and archived on PubMed Central

- yours - you keep the copyright 